\title{
Descendo a montanha e seguindo para o norte: como a degradação do solo e os pesticidas sintéticos orientaram a trajetória da agricultura mexicana ao longo do século $\mathrm{XX}^{*}$
}

\author{
Angus Wright \\ California State University, Sacramento \\ Sacramento, CA, Estados Unidos da América \\ wrighta@saclink.csus.edu
}

\begin{abstract}
RESUMO
A estratégia de desenvolvimento do México no século XX promoveu novos investimentos agrícolas nos desertos do norte e em vales tropicais nas terras baixas. A facção política conhecida como "Dinastia de Sonora" desempenhou um papel político e intelectual fundamental nesta tendência. Além disto, uma crise durante o governo Cárdenas (1934-40) conduziu a um acordo entre os EUA, a Fundação Rockefeller e o presidente mexicano eleito em 1940 para elaborar um programa de pesquisa agrícola conhecido como "A Revolução Verde", que dominou as políticas agrícolas do país, impactando os padrôes de desenvolvimento ao redor do mundo. A estratégia era baseada em certa visão dos solos mexicanos e na disponibilidade de pesticidas e fertilizantes sintéticos. Combinando consulta a arquivos, fontes secundárias, observaçóes e entrevistas, o presente artigo examina as profundas raízes históricas desses acontecimentos e suas consequências, tanto as desejadas como as imprevistas.
\end{abstract}

Palavras-chave: Revolução Verde; México; história agrária; história ambiental; século XX.

\begin{abstract}
Mexico's strategy of development in the twentieth century tended to drive new agricultural investments into Mexico's northern deserts and a few lowland tropical valleys. A conjuncture of factors created this trend. The political faction known as "the Sonoran Dynasty" that dominated Mexico's post-revolutionary governments played a critical political and intellectual role. A political crisis resulting from a challenge to the Sonoran vision during the Cardenas government (1934-40) led to an agreement between the United States government, the Rockefeller Foundation, and the Mexican President elected in 1940 to create a program of agricultural research. The development strategy based on this research, which came to be called "The Green Revolution," would dominate Mexican agricultural policies and would also have a major impact on development patterns around the world. Using a combination of archival, secondary, observational, and interview methods, this article examines the deep historical roots of these events and their intended and unintended consequences.
\end{abstract}

Keywords: Green Revolution; Mexico; agrarian history; environmental history; $20^{\text {th }}$ century.

\footnotetext{
* Tradução do inglês de Sérgio Lamarão. Uma versão abreviada deste artigo será publicada em BOYER, Chris (Org.). $A$ land between waters: environmental histories of Modern Mexico. Tucson: University of Arizona Press. No prelo.

Artigo recebido em 9 de abril de 2012 e aceito em 6 de maio de 2012.
} 
DESCENDO A MONTANHA E SEGUINDO PARA O NORTE: COMO A DEGRADAÇÃO DO SOLO E OS PESTICIDAS SINTÉTICOS ORIENTARAM A TRAJETÓRIA DA AGRICULTURA MEXICANA AO LONGO DO SÉCULO XX

$$
\text { Angus Wright }
$$

A paisagem física do México foi transformada pelo modo com o que o governo mexicano respondeu ao velho problema da degradação do solo do país. A resposta envolveu uma opçáo por obras de irrigação em larga escala e pelo uso de pesticidas e fertilizantes sintéticos. Essa transformação da paisagem tem múltiplas implicaçôes econômicas, políticas e culturais, não apenas para a sociedade mexicana, mas também para todo o planeta. Dirigentes mexicanos e consultores técnicos dos Estados Unidos justificaram o caminho escolhido para o desenvolvimento agrícola com base numa visão de que os solos do México eram naturalmente pobres e profundamente degradados pelo uso contínuo e excessivo. A estratégia foi apoiada com determinação pela Fundação Rockefeller e pelo governo dos Estados Unidos porque ambos consideraram-na desejável para o México e porque o caso mexicano era visto como uma espécie de campo de testes experimental para a política norte-americana, que poderia se mostrar altamente favorável às metas comerciais dos EUA e de sua política externa. Nesse sentido, ela foi, talvez, o exemplo mais significativo de um esforço maior para promover os objetivos do governo e dos interesses privados norte-americanos em todo o mundo, mediante o recurso à competência tecnológica e científica, exercida, ao menos em teoria, de acordo com os interesses mútuos de todos os envolvidos.

Embora tivesse raízes mais profundas, o projeto desta estratégia específica guardava uma direta relação com a situação política no México no início da Segunda Guerra Mundial e tornou-se a fórmula para aquilo que viria a ser chamado de Revolução Verde, que transformou economias e paisagens em todo o mundo e que se tornou o modelo de desenvolvimento agrícola internacional e elemento central da política externa norte-americana no período da Guerra Fria. Ela representou um importante fator, bastante analisado, para o grande êxodo da populaçáo rural em todo o mundo. No México, como em todo o mundo tropical e subtropical, um de seus resultados foi a tendência a fazer o desenvolvimento econômico descer das montanhas para as planícies úmidas e os vales desérticos, o que acarretou uma gama de consequências políticas, culturais e econômicas ${ }^{1}$.

No século XX, considerando as áreas tradicionais da agricultura mexicana naturalmente inadequadas e esgotadas pelo uso, os dirigentes mexicanos e seus assessores estrangeiros olharam para o norte, na direção dos vales desérticos — onde projetos de irrigação em larga escala, financiados pelo Estado, puderam tirar vantagem da terra que fora relativamente pouco usada e pouco danificada - , bem como na direção das planícies tropicais úmidas, mais para o sul. As tecnologias agrícolas desenvolvidas para aproveitar esses vales desérticos ao norte e os solos tropicais úmidos dependiam integralmente do emprego de fertilizantes e pesticidas sintéticos recém-inventados. Este texto conta a história de como a abordagem dominante para lidar com a degradação do solo no México tornou-se de tal maneira entremeada com o uso do pesticida que acabou moldando o destino do campo e da populaçáo rural do México.

Os novos pesticidas sintéticos, além de representarem uma parte essencial do que viria a ser chamado de "o pacote" das tecnologias da Revolução Verde, também pareciam oferecer uma solução aparentemente simples para doenças humanas transmitidas por insetos, nascidas no Velho Mundo, particularmente a malária, que ainda hoje não podem ser controladas pela vacinação. Essas doenças foram introduzidas no México durante a Conquista e tendiam a impelir densas populaçóes humanas das planícies úmidas para as zonas mais elevadas, afastando-as das áreas tropicais úmidas, infestadas de mosquitos. Agrônomos, sanitaristas e políticos acreditavam que se pudessem ser controladas as pragas que afetavam as colheitas tropicais e as doenças epidêmicas que grassavam entre a força de trabalho agrícola, uma nova era se abriria para os trópicos úmidos.

Foi com base nessa visão dos problemas do México com solos e doenças que, por volta de meados do século XX, os agroquímicos sintéticos tornaram-se uma ferramenta importante na superação de uma

\footnotetext{
${ }^{1}$ Essa história é contada com muito mais detalhe, mas com ênfase diferente, em WRIGHT, Angus. The death of Ramon Gonzalez: the modern agricultural dilemma. 2. ed. Austin: University of Texas Press, 2005.
} 
DESCENDO A MONTANHA E SEGUINDO PARA O NORTE: COMO A DEGRADAÇÃO DO SOLO E OS PESTICIDAS SINTÉTICOS ORIENTARAM A TRAJETÓRIA DA AGRICULTURA MEXICANA AO LONGO DO SÉCULO XX

$$
\text { Angus Wright }
$$

variedade de barreiras que se erguiam no caminho de um uso mais completo dos recursos das terras do México e de sua população humana cada vez maior. Solos esgotados podiam ser deixados para trás e novas terras foram disponibilizadas para produzir nas fronteiras econômicas, em expansão. Percebeu-se que uma civilização humana muito antiga tinha ampliado as fronteiras de uma terra recém-produtiva e de assentamentos humanos florescentes.

Isso não se demonstraria um caminho tão direto para a prosperidade e a felicidade, como parecera na metade do século. A estratégia de desenvolvimento econômico que abriu novas fronteiras foi consideravelmente afetada por uma combinação de problemas ecológicos, econômicos e de saúde inerentes às tecnologias recém-adotadas na produção agrícola. Embora permitisse um rápido crescimento econômico, ela também mantinha, tirava vantagem e, de alguma maneira, ampliava as já profundas desigualdades na sociedade mexicana. $\mathrm{O}$ início do século XXI encontrou muitos mexicanos buscando novos arranjos políticos, enquanto, ao mesmo tempo, procuravam por soluçóes mais sustentáveis para o problema ancestral de manutenção da saúde do solo e, com ele, da saúde da sociedade humana.

\section{O cenário pré-colombiano e colonial}

Os povos da antiga Mesoamérica interessavam-se profundamente pelo problema da erosão do solo. $\mathrm{Na}$ condição de inventores de uma ampla gama das plantas agricultáveis do mundo, particularmente o milho, os agricultores mesoamericanos mantinham uma complexa relação com a terra cultivada, que data de mais de novecentos anos antes da chegada dos espanhóis ${ }^{2}$. Os povos pré-colombianos, por exemplo, construíram terraços projetados para maximizar a produção, ao mesmo tempo que protegiam os declives contra a erosão. Alguns deles são usados ainda hoje, e os restos de muitos ainda podem ser reconhecidos. Há também bastante evidência das dificuldades de se controlar a erosão do solo e de seus fracassos enormes em fazer isso ${ }^{3}$. Arqueólogos identificaram que importantes momentos da perda de solo coincidiram com o início do florescimento da agricultura baseada no milho, e talvez tenham sido causados por ele 4 . Tanto o sucesso quanto o fracasso deixaram uma vívida herança de conhecimento e de técnicas entre os agricultores mexicanos tradicionais, voltada para a proteção dos solos contra a erosão e para a manutenção ou a restauração da fertilidade perdida. Recente pesquisa sugere, por exemplo, que os antigos maias experimentaram momentos de grave erosão no começo do Período Clássico, mas aparentemente aprenderam a reduzir as taxas de erosão enquanto a população aumentava, em vez de, conforme se pensava anteriormente, terem sofrido com taxas de erosão mais acentuadas durante o Período Clássico até o colapso5.

Independentemente do que possa ter ocorrido antes da sua chegada, os espanhóis ficaram profundamente impressionados com as habilidades produtivas das culturas que encontraram.

\footnotetext{
${ }^{2}$ RABIELA, Teresa Rojos. Agricultura indígena: pasado y presente. Cidade do México: Ediciones de la Casa Chata, 1994. ${ }^{3}$ WILKEN, Gene. Good farmers: traditional agricultural resource management in Mexico and Central America. Berkeley: University of California Press, 1987.

${ }^{4}$ BUNNEY, Sarah. Prehistoric farming caused devastating soil erosion. New Scientist, v. 125, n. 1.705, p. 20, 1990; O'HARA, S. L. et al. Accelerated soil erosion around a Mexican highland lake caused by prehispanic agriculture. Nature, v. 362, n. 6.415, p. 48-51, 1993; FISHER, C.T. et al. A reexamination of human-induced environmental change within the Lake Patzcuaro Basin, Michoacan, Mexico. Proceedings of National Academy of Sciences, v. 100, n. 8, p. 4957-4962, 2003; ANSELMETTI, Flavio S. et al. Quantification of soil erosion rates related to ancient Mayan deforestation. Geology, v. 35, n. 10, p. 915-918, 2007.

${ }^{5}$ ANSELMETTI, Flavio S. et al. Quantification of soil erosion, op. cit. p. 917.
} 
DESCENDO A MONTANHA E SEGUINDO PARA O NORTE: COMO A DEGRADAÇÃO DO SOLO E OS PESTICIDAS SINTÉTICOS ORIENTARAM A TRAJETÓRIA DA AGRICULTURA MEXICANA AO LONGO DO SÉCULO XX

$$
\text { Angus Wright }
$$

Uma (...) óbvia constatação dos invasores espanhóis era que as paisagens de cultivo e assentamento humano no México eram esteticamente agradáveis, geridas com cuidado e manifestamente prósperas. Os habitantes indígenas do México pré-conquista tinham construído sistemas de horticultura produtiva, meticulosamente intensivos, quase sempre irrigados, talhados para cada uma das principais regióes ecológicas: as planícies litorâneas, a base dos morros e as amplas bacias semiáridas, cercadas por vulcóes do platô elevado. Esses sistemas de cultivo eram tão bem-sucedidos que os habitantes produziam grandes quantidades de alimentos para consumo próprio e até mesmo excedentes ${ }^{6}$.

Os diferentes e engenhosos métodos usados para alcançar esse impressionante resultado refletiam uma resposta historicamente evoluída para as oportunidades e os desafios oferecidos pela paisagem do México, cuja geografia física, imponente e variada, criara uma extraordinária diversidade de biomas, espécies e solos. A atividade vulcânica, presente em boa parte da regiáo, deu origem a alguns solos extraordinariamente férteis, ricos sobretudo em fosfato e potássio, embora muitas vezes pobres em nitrogênio. Os vulcóes também criaram muitos solos excessivamente estéreis, duros demais ou tóxicos demais para a agricultura, e mesmo em pleno século XX (como a erupção, em 1942, no estado de Michoacán, daquele que seria conhecido como Paricutín), em alguns lugares vulcóes simplesmente destruíram terras férteis sob toneladas de rocha inaproveitáveis ou lixo tóxico. Essa elevada produtividade, que deriva da combinação de altos índices de chuva com a intensa luz solar tropical, contribui para a presença de grandes quantidades de matéria orgânica nos solos de diversas regióes, mas a mesma chuva pesada que alimenta uma luxuriante vida vegetal frequentemente cai sob a forma de tempestades violentas e torrenciais, capazes de provocar uma rápida erosão do solo. Chuvas fortes podem também carregar consigo os nutrientes do solo, especialmente quando ele está sendo usado para cultivo. A estrutura granular particular dos solos em muitas regióes — por exemplo, os planaltos mixtecas de Oaxaca — torna-os peculiarmente propensos à erosão. Solos desérticos potencialmente férteis são quase sempre o produto de milhóes de anos de depósito aluvial, proveniente de terrenos mais elevados e que floresce, de forma exagerada, com a irrigação. Esses solos, contudo, tendem a estar sujeitos a graves problemas de salinidade e lençóis d'água suspensos (onde superfícies impermeáveis sob a camada superficial do solo acarretam uma drenagem pobre e o acúmulo de água salgada na altura onde raízes deveriam se desenvolver), quando empregados para fins de agricultura intensiva. Em boa parte do México, a topografia escarpada e acidentada basta para acarretar problemas significativos de erosáo, com a chuva que lava o solo das encostas cultivadas, asfixiando os ricos solos de pastagens e vales com sedimentos que são, às vezes, inférteis, e enviando água de chuva que escorre das encostas dos montes para os terrenos mais planos. Ao mesmo tempo, sedimentos liberados pelas chuvas, ao descerem pelas encostas das montanhas, podem, algumas vezes, fornecer novos nutrientes aos solos dos vales?

Um aparente paradoxo da história da Mesoamérica anterior à invasão espanhola advém da relação de culturas sofisticadas com as características dos solos mexicanos. Acredita-se que somente as áreas de planalto que se encontravam sob o amplo controle asteca teriam reunido uma população da ordem de 14 milhôes de pessoas ${ }^{8}$. O paradoxo é que densidades demográficas notavelmente elevadas podiam ser sustentadas por sociedades agrícolas numa base territorial a qual, da perspectiva de muitos nos séculos XIX e XX, parecia incapaz de fazê-lo. A resolução do paradoxo encontra-se na elevada fertilidade potencial de um terreno que, ao mesmo tempo, era muito vulnerável à degradaçáo. A paisagem que

\footnotetext{
${ }^{6}$ RICHARDS, John. The unending frontier: an environmental history of the early modern world. Berkeley: University of California Press, 2003. p. 300.

7 BATTALLA, Angel Bassols. Recursos naturales de México: teoría, conocimiento y uso. Cidade do México: Editorial Nuestro Tiempo, 1982.

${ }^{8}$ RICHARDS, John. The unending frontier, op. cit. p. 340.
} 
DESCENDO A MONTANHA E SEGUINDO PARA O NORTE: COMO A DEGRADAÇÃO DO SOLO E OS PESTICIDAS SINTÉTICOS ORIENTARAM A TRAJETÓRIA DA AGRICULTURA MEXICANA AO LONGO DO SÉCULO XX

Angus Wright

observadores em tempos recentes viam no México era uma paisagem transformada pelo uso humano. A capacidade de reavaliar tanto a fertilidade quanto a vulnerabilidade dos solos do México é um elemento-chave para compreender a história da nação.

Os trabalhos do geólogo Sherburne Cook, dos historiadores Woodrow Wilson Borah e Lesley Bird Simpson, e do geógrafo Carl Sauer, em meados do século XX, moldaram originalmente esta explicação, a fim de usar a história da erosão do solo, combinada com o registro documental, para descerrar a história do colapso demográfico no México (e, por extensão, no Novo Mundo como um todo), abrindo nossos olhos para interpretaçôes inteiramente novas da história do México e de todas as Américas ${ }^{9}$. Isso, por sua vez, ajudou a iluminar o caminho para a história social de François Chevalier e para a "etno-história” de Charles Gibson, William Taylor, James Lockhart e outros ${ }^{10}$. O trabalho inovador de Elinor Melville, aluna de Gibson, em uma das mais importantes obras da nova safra da história ambiental, levou-nos a voltar aos temas desenvolvidos por Cook e Borah, oferecendo-nos, ao mesmo tempo, um quadro mais completo e detalhado do efeito da Conquista na paisagem mexicana e em seus povos ${ }^{11}$.

A despeito da força dessa corrente dos estudos históricos, nem sempre os historiadores reconheceram o papel da erosão do solo, nem suas complexidades e contradiçôes potenciais. Isso se deve parcialmente à sua incapacidade de compreender integralmente a efetividade das técnicas de administração intensivas empregadas pelos agricultores pré-colombianos e os danos causados pela Conquista. Com consequências mais diretas e talvez mais cruciais para o México e boa parte do mundo, agrônomos e cientistas agrícolas não foram capazes de atingir esse nível de compreensão. Predisposiçóes ideológicas e objetivos políticos dos observadores no século XX referentes ao que percebiam como incapacidade do México de alimentar-se de forma confiável quase sempre embaçaram a visão formada acerca do passado do país.

Como vimos, a avaliação inicial dos colonizadores espanhóis acerca da agricultura indígena era de franca admiração pela "prosperidade manifesta" que os povos mexicanos tinham atingido. O exemplo que se tornou mais evidente e que mais impressionou os espanhóis foi a agricultura chinampa, de onde provinha a maior parte dos alimentos, das plantas medicinais e, o que náo era trivial do ponto de vista asteca, das flores consumidas em Tenochtitlán (a moderna Cidade do México), entáo uma das maiores cidades do mundo. Os campos artificialmente construídos dos chinampas, estabelecidos no leito raso do lago Texcoco, criaram uma das formas mais produtivas de agricultura já inventadas pelos seres humanos, que só encontrava rival nos campos de arroz intensivamente cultivados da Ásia, ou nos sistemas modernos, ainda mais intensivamente baseados em produtos químicos. Até imediatamente antes da Segunda Guerra Mundial, a agricultura chinampa fornecia a maior parte dos alimentos e das flores para o então 1 milhão de habitantes da Cidade do México, embora a maior parte da água de que o sistema dependia tivesse sido drenada, apropriada para outros usos, e estivesse poluída ${ }^{12}$. Esse é apenas um exemplo das muitas maneiras com que os agricultores mexicanos tradicionais foram capazes de sustentar as elevadas densidades populacionais sem recorrer a químicos sintéticos nem às espécies altamente produtivas criadas no século XX. Trabalho arqueológico recente também tem produzido maiores evi-

\footnotetext{
9 SAUER, Carl. Aboriginal population of Northwestern Mexico. Ibero-Americana, Berkeley, n. 10, 1930; COOK, Sherburne F.; SIMPSON, Lesley Bird. The population of Central Mexico in the sixteenth century. Ibero-Americana, Berkeley, n. 31, 1948; COOK, Sherburne F. Soil erosion and population in central Mexico. Ibero-Americana, Berkeley, n. 34, 1949; ; BORAH, Woodrow. The Indian population of Central Mexico, 1531-1610. Ibero-Americana, Berkeley, n. $44,1960$.

${ }^{10}$ CHEVALIER,François. Land and society in Colonial Mexico. Berkeley: University of California Press, 1971; GIBSON, Charles. The Aztecs under Spanish rule. Stanford: Stanford University Press, 1964; TAYLOR, William B. Landlord and peasant in Colonial Oaxaca. Stanford: Stanford University Press, 1972.

${ }^{11}$ MELVILLE, Elinor G. K. A plague of sheep: environmental consequences of the conquest of Mexico. Cambridge: Cambridge University Press, 1994.

${ }^{12}$ SCHILLING, Elisabeth. Los “jardines flotantes” de Xochimilco (1938). In: ROJOS RABIELA, Teresa (Org.). La agricultural chinampera. Chapingo: Universidad Autónoma Chapingo, 1983.
} 
DESCENDO A MONTANHA E SEGUINDO PARA O NORTE: COMO A DEGRADAÇÃO DO SOLO E OS PESTICIDAS SINTÉTICOS ORIENTARAM A TRAJETÓRIA DA AGRICULTURA MEXICANA AO LONGO DO SÉCULO XX

Angus Wright

dências comprovando que em diversos períodos do tempo pré-colonial a maior parte das planícies tropicais no México e na Guatemala dependia igualmente das chinampas, com uma agricultura desenvolvida em ambientes lacustres ou pantanosos ${ }^{13}$. Nas terras secas do México, os povos indígenas construíram canais de irrigação para adaptar a produção de alimentos à aridez e à seca ${ }^{14}$. Tomadas conjuntamente, essas técnicas nos lembram que, ainda que discutamos neste artigo as perdas em termos de fertilidade infligidas aos solos tanto antes quanto depois da Conquista espanhola, os agricultores mexicanos, anteriormente ao contato com os europeus, estavam envolvidos em uma gestão extremamente sofisticada e normalmente bem-sucedida dos recursos do solo ${ }^{15}$.

Há notáveis exceçóes na história do México pré-Conquista, mas as crises de subsistência no México pré-hispânico, se algumas vezes foram impressionantes, raramente ocorriam devido à ignorância dos povos indígenas a respeito dos métodos para controlar a erosão do solo. Ao contrário, devemos certamente procurar combinações de fatores naturais - que estabelecem limites àquilo que os agricultores podiam realizar com sucesso - com determinados aspectos da organização social se quisermos compreender as causas da erosão ou da degradação do solo. $\mathrm{O}$ argumento, que sobrevive há décadas, sobre o possível papel do esgotamento agrícola no colapso da cultura maia clássica, por exemplo, demonstra, repetidamente, que embora a degradação do solo possa ter constituído um importante fator para o colapso, ela só se torna convincente ou inegável se considerarmos os fatores sociais e políticos que explicariam por que esses agricultores, obviamente muito capazes, não conseguiram responder em tempo aos primeiros sinais do problema. Precisamos saber também por que o colapso foi táo rápido, e não um longo declínio em direção a uma crescente privação nutricional, em relação à qual há poucas evidências do que se esperaria encontrar.

Se é verdade que as principais comoçôes sociais ocorreram como uma consequência da degradação do solo da Mesoamérica antes da Conquista, é igualmente verdadeiro que as culturas mesoamericanas aprenderam muito sobre como gerenciar a fertilidade e a erosão do solo ${ }^{16}$. A profunda transformação, em larga medida para pior, dos solos do México no período colonial - muitas vezes erradamente interpretada, ao longo dos séculos, como um sinal dos fracassos indígenas - deveu-se, antes, às diferentes tecnologias agrícolas, objetivos, organizaçáo social e base de conhecimento dos espanhóis do que à inadequação dos conhecimentos ou das técnicas dos indígenas.

Essas questôes, contudo, são complexas e não podem ser baseadas numa visão edênica do México pré-Conquista e de seus habitantes. A admiração pela técnica indígena não deve obscurecer seus fracassos nem os problemas presentes em alguns de seus sucessos. Um dos exemplos mais significativos da gestão do solo no México pré-Conquista ocorreu na área dominada pelo povo mixteca, onde se encontra hoje o estado de Oaxaca. Acredita-se que a sociedade mixteca pré-Conquista foi "a sociedade mais profundamente estratificada na Mesoamérica" ${ }^{17}$. Seus métodos agrícolas refletiam acentuadas diferenças entre governantes e governados. Os vales eram controlados pela nobreza hereditária. A própria nobreza pode ter se imposto ao povo mixteca. Os antigos códices mixtecas afirmavam que o povo mixteca tinha nascido da terra, mas também se referiam à história de um grupo de reis nascidos das árvores, no norte, e que vieram, por volta de 1000 d.C., a governar os mixtecas. Aproximadamente

\footnotetext{
${ }^{13} \mathrm{BEACH}$, Tim et al. A review of human and natural changes in Maya lowland wetlands over the Holocene. Quaternary Science Reviews, v. 28, n. 17-18, p. 1710-1724, Mar. 2009.

${ }^{14}$ DOOLITTLE, William E. Cultivated landscapes of native North America. Oxford: Oxford University Press, 2000.

${ }^{15}$ ROJAS RABIELA, Teresa (Org.). La agricultura chinampera, op. cit.

${ }^{16}$ DEMAREST, Arthur A.; RICE, Prudence; RICE, Don S. (Org.). The Terminal Classic in the Maya lowlands: collapse, transition, and transformation. Boulder: University of Colorado Press, 2004.

${ }^{17}$ FLANNERY, Kent. Precolumbian farming in the Vales of Oaxaca, Nochixtlan, Tehuacan, and Cuicatlan: a comparative study. In: __ _ MARCUS, Joyce (Org.). The cloud people: divergent evolution of the Zapotec and Mixtec civilization. Nova York: Academic Press, 1983. p. 218.
} 
DESCENDO A MONTANHA E SEGUINDO PARA O NORTE: COMO A DEGRADAÇÃO DO SOLO E OS PESTICIDAS SINTÉTICOS ORIENTARAM A TRAJETÓRIA DA AGRICULTURA MEXICANA AO LONGO DO SÉCULO XX

$$
\text { Angus Wright }
$$

$30 \%$ da população que não pertencia à nobreza trabalhavam diretamente para as famílias nobres, com base numa relação um pouco semelhante à servidão europeia, estando sua força de trabalho à disposição da nobreza sob a forma de corveias ou de trabalho obrigatório. Os demais camponeses ganhavam a vida trabalhando nas íngremes escarpas do rochoso terreno mixteca. $\mathrm{Na}$ medida em que ricos solos formados sob florestas de pinheiros e carvalhos eram deflorestados e aproveitados para a agricultura, o solo inevitavelmente se deslocava das encostas para baixo, em direçáo aos vales da nobreza. Os nobres, em algum momento, perceberam que havia uma riqueza a ser aproveitada. Eles orientaram os trabalhadores a construir pequenas represas nos vales e cânions para aproveitar a água que escorria e se apropriar do solo. Essas represas passaram a fazer as vezes de terraços irrigados de terras de vale, visto que proliferavam em sistemas cuidadosamente projetados de retenção de solo e água. Os ricos vales da nobreza tornaram-se mais amplos e os solos mais profundos. Mesmo os cânions em forma de V, que originalmente eram completamente inadequados para a agricultura, foram transformados em ricos terrenos de vale. Os camponeses tornavam-se cada vez mais pobres e desesperados, enquanto seus campos, laboriosamente desmatados, eram despojados de seus nutrientes, impelindo-os a migrar para áreas mais elevadas e mais íngremes. $\mathrm{O}$ aumento da riqueza dos nobres guardava uma relação direta com o aprofundamento progressivo dos problemas dos pobres. Parece provável que o número de trabalhadores a serviço da nobreza tenha aumentado à medida que aumentaram as dificuldades para os camponeses pobres produzir comida suficiente para seus filhos, nascidos nas encostas erodidas ${ }^{18}$.

$\mathrm{Na}$ regiáo da Mixteca, o sistema que inclui o uso de terraços e pequenas barragens é conhecido como lama y bordo, e uma razão pela qual podemos decifrar o enigma da narrativa arqueológica é que as paredes ainda visíveis dos terraços que marcam as laterais da montanha e das barragens nas terras baixas são compatíveis com muito do que ainda pode ser observado na Mixteca, nos dias de hoje. Se nossa compreensão do sistema estiver correta, o sistema pré-hispânico estava baseado na exploração e na desigualdade. A questão que surge daí é saber se todas essas providências poderiam se manter estáveis no longo prazo. Contudo, a invasão espanhola impediu que essa questão fosse contemplada, uma vez que lançou, imediatamente, todo o sistema numa completa desordem. A introdução de animais de pastagem domesticados nas frágeis escarpas, o uso do arado e a mudança na combinaçáo de cultivares sobrecarregaram o sistema, acelerando a erosão. Em um século, as doenças europeias reduziram a população no Mixteca a talvez $15 \%$ do nível anterior à Conquista. $\mathrm{Na}$ medida em que as taxas de erosão aumentavam com as pastagens e o uso do arado, era difícil reunir a máo de obra necessária para conservar os terraços e as pequenas barragens; mudanças nos sistemas de autoridade e organizaçáo social complicaram ainda mais a questão. Além disso, o governo espanhol tinha objetivos diferentes em mente para a regiáo; o mais importante deles era o fornecimento de mulas para as minas no norte, uma mudança que era incompatível com o esquema mixteca, centrado na produção de alimentos para o consumo humano. A erosão e a degradação do solo avançaram rapidamente. A base de subsistência da terra arável foi reduzida pela ação da erosão em pelo menos $75 \%$, se comparada com aquela disponível na Conquista ${ }^{19}$.

Outras regióes sofreram consequências similarmente desastrosas. Aquela que conhecemos mais é o vale do Mezquital, ao norte da Cidade do México (ironicamente, o suposto lar da nobreza que acabou por dominar a Mixteca). O clássico estudo de Elinor Melville, A plague of sheep, demonstrou que a região que nós vemos hoje, e mesmo aquela que foi observada pelos espanhóis no final do século XVI, foi fundamentalmente alterada para pior. Uma rica região agrícola foi radicalmente transformada por uma série de mudanças resultantes da "praga da ovelha". Tanto de maneira direta quanto indireta, os animais de pastoreio criados pelos espanhóis causaram uma erosão generalizada do solo e um conjunto

\footnotetext{
${ }^{18}$ SPORES, Ronald. The Mixtecs in ancient and modern times. Norman: University of Oklahoma Press, 1984.

${ }^{19}$ WRIGHT, Angus. The death of Ramon Gonzalez, op. cit. cap. 5.
} 
DESCENDO A MONTANHA E SEGUINDO PARA O NORTE: COMO A DEGRADAÇÃO DO SOLO E OS PESTICIDAS SINTÉTICOS ORIENTARAM A TRAJETÓRIA DA AGRICULTURA MEXICANA AO LONGO DO SÉCULO XX

Angus Wright

de modificaçóes infelizes nas características hidrológicas da regiáo, secando nascentes e poços e dando origem a uma escassez crônica de água. Melville aponta que, contrariamente à visão de Alfred Cros$b y^{20}$, a invasão espanhola não criou uma paisagem "neoeuropeia". $\mathrm{Na}$ Conquista, o vale do Mezquital assemelhava-se mais de perto do ideal europeu de uma região agrícola produtiva e fértil, e foi a própria invasão europeia que "a transformou em algo quase sempre percebido como arquétipo das regióes mexicanas 'naturalmente' pobres". Melville explica que

No processo, os Otomí foram deslocados, alienados e marginalizados, sua história e a de sua região, mistificadas. Os Otomí são associados com a estranha paisagem da Conquista, não com paisagens férteis e produtivas de quando o contato foi feito. Suas habilidades como cultivadores foram esquecidas, e sua reputação como comedores de besouros, insetos e do fruto do cactus nopal consolidada ${ }^{21}$.

Ao contrário do que houve na Mixteca, o vale do Mezquital experimentou uma revitalização agrícola no século XX, embora não sem seus próprios problemas e controvérsias, devidos, em grande parte, à importação do esgoto da Cidade do México, usado como fonte de fertilizantes e água.

Talvez uma das transformaçóes mais profundas tenha sido a mais óbvia, aquela que envolveu as chinampas do lago Texcoco que abasteceram Tenochtitlan e a Cidade do México. Os espanhóis admiravam a capital asteca (lembremos o comentário esbaforido, mas preciso, de Bernal del Castillo), mas eles não compreenderam sua base hidrológica. Não sem razóes, eles viam as águas do lago Texcoco como a fonte dos "miasmas" que reproduziram as doenças do Velho Mundo. Tragicamente, eles culpavam as águas do lago como uma causa importante de inundaçóes catastróficas da cidade, em vez de identificarem os efeitos de sua própria negligência e destruição dos canais e diques astecas ou os resultados das políticas urbanas e agrícolas sobre o regime de cheias. Os funcionários espanhóis do período colonial implementaram uma longa campanha para drenar as águas do lago, sobretudo no grande "deságue" da primeira década do século XVII. A redução da área e da produtividade das chinampas terminou por, entre outras coisas, deixar a agricultura na dependência de outras terras produtivas, boa parte delas submetida aos mesmos processos de degradação descritos por Melville. Ao mesmo tempo, muito do conhecimento essencial necessário ao uso mais efetivo do sistema chinampa intensivo se perdeu junto ao solo das escarpas montanhosas ${ }^{22}$.

A erosão e a degradação do solo foram um tema importante na história mexicana por 2 mil ou 3 mil anos. Onde a erosão estava, de alguma maneira, sob controle, como na Mixteca, o sistema de controle algumas vezes representou um preço pesado em vidas humanas e, provavelmente, não era sustentável a longo prazo. Entretanto, recentes afirmaçôes de que registros de erosão nos planaltos de Michoacán e outros acontecimentos relacionados à erosáo ocorridos antes da Conquista excedem em importância os problemas criados pela Conquista não são convincentes ${ }^{23}$. Embora possamos identificar um maciço deslocamento de materiais que desciam morro abaixo por conta do cultivo de milpa muito antes da Conquista, ainda não sabemos o bastante, se é que um dia saberemos, sobre suas causas. Por exemplo, é difícil dizer o quanto dessa erosão foi provocado pela agricultura propriamente dita, e o quanto foi provocado pelas tempestades extraordinariamente fortes, numa região conhecida por suas chuvas torren-

\footnotetext{
${ }^{20}$ CROSBY, Alfred. Imperialismo ecológico: a expansão biológica da Europa: 900-1900. São Paulo: Companhia das Letras, 1993.

${ }^{21}$ MELVILLE, Elinor G. K. A plague of sheep, op. cit. p. 115.

22 SIMON, Joel. Endangered Mexico: an environment on the edge. San Francisco: Sierra Club Books, 1997. p. 64-72; MUSSET, Alaine. El agua en el valle de México: siglos XVI-XVII. Cidade do México: Centro de Estudios Mexicanos y Centroamericanos, 1992.

${ }^{23}$ BUNNEY, Sarah. Prehistoric farming caused devastating soil erosion, op. cit.; O’HARA, S. L. et al. Accelerated soil erosion, op. cit.; ANSELMETTI, Flavio S. et al. Quantification of soil erosion, op. cit.
} 
DESCENDO A MONTANHA E SEGUINDO PARA O NORTE: COMO A DEGRADAÇÃO DO SOLO E OS PESTICIDAS SINTÉTICOS ORIENTARAM A TRAJETÓRIA DA AGRICULTURA MEXICANA AO LONGO DO SÉCULO XX

$$
\text { Angus Wright }
$$

ciais. Além do mais, o que sabemos a respeito dos danos causados aos solos mexicanos após a Conquista é que eles foram generalizados, abrangentes e persistentes através dos séculos. Se esse tivesse sido o caso na era pré-Conquista, é difícil imaginar que os espanhóis tivessem mesmo encontrado as civilizaçôes densamente assentadas e "manifestamente prósperas" que tanto os impressionaram. O fato de que o México, no século XX, tenha sido caracterizado com frequência como um país pobre em termos de seu potencial agrícola resultou, numa medida considerável, de séculos de dominação europeia, que tanto destruiu a terra quanto configurou atitudes que interpretaram a terra devastada como uma herança natural e não como uma criação humana. Pode-se dizer que os espanhóis não apenas descobriram como também criaram um Novo Mundo, e do ponto de vista da agricultura, um mundo mais pobre.

\section{Uma crise cada vez mais profunda}

O impacto sobre as pessoas e a terra durante o primeiro século após a Conquista abriu caminho para uma prolongada depressão econômica que atravessou praticamente todo o século XVII. O deflorestamento e a consequente erosão resultaram tanto do tipo de mudanças agrícolas que caracterizaram a Mixteca e o vale do Mezquital quanto da necessidade de madeira e carvão para as atividades de mineração ${ }^{24}$. Com o decréscimo das populações indígenas, seus direitos à terra formalmente reconhecidos foram minados pelo sistema de trabalho forçado, o repartimiento, que privou as comunidades da autonomia e do trabalho essenciais para seu próprio sustento. Enquanto comunidades sofriam de um generalizado colapso demográfico devido às doenças, os espanhóis lançaram mão tanto de estratégias legais quanto da força para reduzir a extensão de terras disponíveis para as populaçôes indígenas. A situação legal e social era fluida e difícil, e a longa depressão que se instalou durante o século XVII provocou um grande desejo por estabilidade, um dos principais fatores para o crescimento da hacienda ${ }^{25}$.

As haciendas e as missóes religiosas coexistiam com as comunidades indígenas - as quais, sempre que possível, continuaram a proteger suas terras zelosamente — mas também absorviam algumas dessas comunidades e eliminavam outras. ${ }^{26}$ As comunidades também coexistiam com atividades mais diretamente comerciais, como as plantaçôes de cana-de-açúcar. No século XIX, o persistente processo de desapropriação das comunidades indígenas que teve lugar ao longo dos três séculos do período colonial ainda não tinha se completado, e essas comunidades continuavam a controlar cerca da metade da terra arável em Oaxaca, por exemplo, por ocasião da Independência ${ }^{27}$. A legislação sobre terras do século XIX, de cunho liberal — que não foi aplicada de forma consistente, conforme previsto, contra as propriedades da Igreja, mas que se mostrou muito eficiente em se apoderar de terras das comunidades camponesas —, levou a um processo mais rápido de apropriação por parte dos hacendados, das autoridades eclesiásticas e dos empreendimentos empresariais. As estimativas variam, mas exceto as inacessíveis regiôes montanhosas, apenas de 4 a 10\% das terras agrícolas estavam nas mãos de pequenos proprietários e das comunidades indígenas quando teve início a Revolução de $1910^{28}$.

Não sabemos em detalhe o que aconteceu com o solo ao longo do período que se estendeu entre 1600 e 1910. Conhecemos haciendas exemplares, que implementavam excelentes práticas conservacio-

\footnotetext{
${ }^{24}$ BAKEWELL, Peter J. Silver mining and society in Colonial Mexico: Zacatecas, 1546-1700. Cambridge: Cambridge University Press, 1971.

${ }^{25}$ CHEVALIER, François. Land and society in Colonial Mexico, op. cit.; RICHARDS, John. The unending Frontier, op. cit. cap. 10.

${ }^{26}$ GIBSON, Charles. The Aztecs under Spanish rule, op. cit.

${ }^{27}$ TAYLOR, William B. Lord and peasant in Colonial Oaxaca, op. cit.

${ }^{28}$ HART, John. Revolutionary Mexico: the coming and process of the Mexican Revolution. Berkeley: University of California Press, 1987.
} 
DESCENDO A MONTANHA E SEGUINDO PARA O NORTE: COMO A DEGRADAÇÃO DO SOLO E OS PESTICIDAS SINTÉTICOS ORIENTARAM A TRAJETÓRIA DA AGRICULTURA MEXICANA AO LONGO DO SÉCULO XX

Angus Wright

nistas que protegiam solos e florestas, garantindo, assim, a segurança que era o ideal dessas propriedades. Parece provável que onde essas práticas de conservação foram um sucesso, elas dependessem tanto do conhecimento tradicional da população indígena mexicana como das tradiçóes que eram transmitidas por geraçóes entre os espanhóis. As tradições espanholas ajudaram a desenvolver os arranjos pastoris coloniais que, em alguns momentos e em alguns lugares, promoveram um uso inteligente das mudanças sazonais através de vastas paisagens para fazer com que o gado chegasse às minas e aos núcleos populacionais sem provocar danos óbvios às pastagen ${ }^{29}$. Gene Wilken mostrou que, no século XX, os mexicanos praticavam uma engenhosa combinação de técnicas tradicionais para controlar a erosão do solo e lidar com a perda de fertilidade. A originalidade e a cuidadosa adaptaçáo às condiçóes locais e as intricadas maneiras pelas quais essas técnicas são integradas à cultura e à organização social local sugerem fortemente que a maior parte delas foi desenvolvida ao longo de séculos, se não de milênios ${ }^{30}$.

Contudo, também sabemos que a paisagem do México e seu solo continuaram a ser submetidos a um grave e persistente processo de erosão e degradação. A perda de uma vasta porção de seu território na guerra com os Estados Unidos privou o México de uma grande extensão de terra com a qual o ministro da Economia, Lucas Alemán, esperava contrabalançar as insistentes pressões sobre terras cada vez mais disputadas no planato central. Os conselheiros de Porfirio Díaz consideravam essencial, pelas mesmas razóes, o desenvolvimento agrícola naquilo que restara do norte. No século XX, o México tornou-se um exemplo muito citado de um país esgotado pelos danos sofridos por seus solos e que necessitava de uma estratégia agrícola de recuperação ou transformação.

O historiador ambiental Lane Simonian assinalou o paradoxo, aparentemente curioso, de que, com todos os problemas que o México experimentou, ao longo de tanto tempo, com a erosão, tanto o governo colonial quanto o governo nacional tenham concentrado seus esforços conservacionistas nas florestas e dedicado pouca atenção aos solos ${ }^{31}$. Esse paradoxo pode não ser tão indecifrável como parece. Por um lado, as florestas desempenham um papel importante na limitação da erosão do solo e na construção de sua fertilidade, e Simonian destaca corretamente que os observadores mexicanos foram mais perspicazes e rápidos em reconhecer esse fato do que seus correspondentes nos Estados Unidos $^{32}$. Isso é especialmente verdadeiro no terreno acidentado de boa parte do México, onde o deflorestamento de encostas íngremes frequentemente implica desastres para os terrenos aráveis situados abaixo, e onde as técnicas camponesas para manter a fertilidade dependem, quase sempre, do cuidadoso manejo do material orgânico da floresta e de sua incorporaçáo aos campos de cultivo. Por outro lado, as florestas em grande medida se localizavam em terras comunais do Estado ou de comunidades indígenas, onde eram legalmente sujeitas ao monitoramento dos governos e/ou das comunidades, enquanto era muito mais difícil controlar as práticas agrícolas empreendidas por milhóes de proprietários rurais individuais. As instituiçôes do Estado e as tradiçôes voltadas aos cuidados com a floresta remontam ao período que antecede a colonização europeia, assim como as tradiçóes comunais no México. O princípio subjacente à política governamental de controle das florestas se apoia frequentemente em parte sobre o argumento de que o tempo necessário para o crescimento das árvores requer um comprometimento de longo prazo por parte do governo ao manejo não comercial,

\footnotetext{
${ }^{29}$ BUTZER, Karl W.; BUTZER, Elizabeth K. Transfer of the Mediterranean livestock economy to New Spain: adaptation and ecological consequences. In: TURNER, B. L. Global land use change: a perspective from the Columbian encounter. Madri: Consejo Superior de Investigaciones Cientificas, 1995.

30 WILKEN, Gene. Good farmers, op. cit. A comparação de técnicas descritas por Wilken com aquelas discutidas em Doolittle (Cultivated landscapes of native North America) também sugere fortemente a longa procedência de técnicas ainda em uso.

${ }^{31}$ SIMONIAN, Lane. Defending the land of the jaguar: a history of conservation no México. Austin: University of Texas Press, 1995. p. 2.

${ }^{32}$ Ibidem, p. 49-50.
} 
DESCENDO A MONTANHA E SEGUINDO PARA O NORTE: COMO A DEGRADAÇÃO DO SOLO E OS PESTICIDAS SINTÉTICOS ORIENTARAM A TRAJETÓRIA DA AGRICULTURA MEXICANA AO LONGO DO SÉCULO XX

Angus Wright

enquanto no processo de tomada de decisão das atividades agrícolas, por ser mais imediato, respostas individuais aos mercados são mais adequadas. Essas consideraçóes ajudam a entender por que, no México, os comentaristas expressaram por tanto tempo suas preocupaçôes com as florestas e também com os solos, embora as florestas tenham sido manejadas, parcialmente, por políticas governamentais tanto no período colonial como nacional, e os solos não.

Um pouco de perspectiva comparativa também é útil. Muito daquilo que Simonian descreve como atitudes do governo mexicano em relação aos solos e às florestas também pode ser aplicado à política governamental implementada na Europa e nos Estados Unidos. Na Europa, as preocupaçóes governamentais medievais e do século XIX com as florestas antecederam em muito qualquer esforço oficial significativo em relação aos solos. As autoridades norte-americanas atuaram no sentido de proteger as florestas antes de considerar seriamente a erosão do solo. Tanto nos Estados Unidos quanto na Europa, o declínio patente e continuado da fertilidade do solo foi enfrentado pelos governos, em grande medida, através da busca de novas fontes de nutrientes mesmo que além das fronteiras nacionais, mais notadamente na corrida para a exploração das ilhas de guano no litoral do Peru — um esforço que se tornou muito menos importante após o processo Haber-Bosch de produção de amônia, inventado em 1909 e que começou a ser aplicado em escala industrial em 1913 ${ }^{33}$. Nos Estados Unidos, a intensificação da produção em novas fronteiras abertas continuou a ser um foco central da política agrícola, exemplificada, em parte, pela aprovação do Reclamation Act de 1902, destinado a assegurar irrigação às fronteiras agrícolas dos vales áridos e semiáridos do Oeste e do Sudoeste. Embora tenha sido instaurado no Departamento de Agricultura no mesmo ano em que o Serviço de Florestas (1901), a Divisão de Solos estava primordialmente preocupada com a classificação de solos, no intuito de promover e posicionar novos assentamentos. Em 1909, a Divisão anunciou que "o solo é o único ativo indestrutível e imutável que a nação possui. É o único recurso que não pode ser esgotado e que não pode ser usado até o fim"34. Todavia, seria necessário esperar até 1935 para que surgisse uma iniciativa do governo dos Estados Unidos em relação à conservação do solo, embora bastante imperfeita, que foi a criação do Serviço de Conservação do Solo, e apenas como uma resposta ao desastroso Dust Bowl ${ }^{35}$. Simonian destaca que o primeiro programa efetivo de governo mexicano voltado diretamente para o combate à erosão do solo só foi lançado nos anos 1940, embora os funcionários federais tenham começado a ocupar-se da questão na década de 1930, contemporaneamente às apreensóes mais sérias do governo de Washington. Aldo Leopold escreveu, a respeito das iniciativas dos Estados Unidos nas décadas de 1930 e 1940, que a política governamental era deploravelmente inadequada à missão. "Ela não define o que é certo ou o que é errado, não atribui nenhuma obrigação, não implica nenhum sacrifício, nenhuma mudança na filosofia atual de valores. No que diz respeito ao uso da terra, recomenda apenas um egoísmo esclarecido" ${ }^{36}$. Não é de se surpreender que, no México, o caminho escolhido com a assessoria dos especialistas agrícolas norte-americanos tenha sido definido de uma maneira deliberadamente voltada para promover deslocamentos regionais que favorecessem a expansão da agricultura comercial, muito mais do que a conservação ou a recuperação de solos nas regiôes agrícolas tradicionais do país.

\footnotetext{
${ }_{33}$ CUSHMAN, Gregory T. The lords of guano: science and the management of Peru's Marine environment, 1800-1973 Tese (Doutorado) — University of Texas, Austin, 2003.

${ }^{34}$ Citado em WORSTER, Donald. The Dust Bowl: the southern plains in the 1930s. Oxford: Oxford University Press, 1979. p. 213.

${ }^{35}$ Foi um período de devastadoras tempestades de areia que causaram sérios prejuízos ecológicos e à agricultura nas planícies dos Estados Unidos e do Canadá, na década de 1930, particularmente em 1934 e 1936. (N.T.)

${ }^{36}$ LEOPOLD, Aldo. The Sand County Almanac. San Francisco: Sierra Club Books, 1970 [1949]. p. 244.
} 
DESCENDO A MONTANHA E SEGUINDO PARA O NORTE: COMO A DEGRADAÇÃO DO SOLO E OS PESTICIDAS SINTÉTICOS ORIENTARAM A TRAJETÓRIA DA AGRICULTURA MEXICANA AO LONGO DO SÉCULO XX

Angus Wright

\section{Escolhas revolucionárias ou escolhas contrarrevolucionárias feitas por revolucionários?}

Os líderes que subiram ao poder nacional em consequência da vitória da Revolução Mexicana não estavam preocupados com a redistribuição de terras a um campesinato sem poder político, por mais que isso estivesse entre os principais temas da luta revolucionária. Em muitos estados, os governadores promoveram programas de reforma agrária agressivos e algumas vezes radicais tanto quanto permitiam seus poderes, e às vezes com retrocessos posteriores. Em âmbito nacional, contudo, as partes da Constituição de 1917 que presidiram a legislação agrária mexicana até 1992, com emendas substanciais, não garantiam minimamente a realização de uma reforma agrária séria. Emiliano Zapata, que levantou a bandeira da causa camponesa e insistiu na reforma agrária como parte integrante da Constituição, foi assassinado em 1919. Francisco Villa, visto por alguns como um líder do campesinato rural socialmente excluído, embora seus compromissos e visões não fossem consistentes como os de Zapata, não assumiu nenhum posto oficial até o fim da guerra revolucionária e foi assassinado em 1924. O governador de Sonora, general Álvaro Obregón, tornou-se o presidente Obregón em 1920, e seu sucessor, Plutarco Elías Calles, também provinha do mesmo estado da fronteira norte do México. Eles lideravam um grupo de dirigentes políticos, conhecido como a Dinastia de Sonora, que controlou o governo mexicano até 1934. A Dinastia de Sonora tinha realmente uma nova visão para a agricultura mexicana, mas que contrastava fortemente com a visão de Zapata de um campesinato comunal ${ }^{37}$.

Obregón e Calles foram demonizados nos Estados Unidos por seu pretenso radicalismo, ainda que de um tipo peculiar, e, de fato, mostraram-se dispostos a enfrentar o governo norte-americano em disputas originadas na Constituição revolucionária e nas apreensóes dos empresários norte-americanos acerca da segurança dos seus investimentos. Isso tendeu a obscurecer o fato, muito mais significativo no longo prazo, de que esses dois líderes da Dinastia de Sonora eram sócios de investidores norte-americanos no desenvolvimento da agricultura irrigada e de empresas industriais associadas. Estradas de ferro e facilidades portuárias instaladas no golfo da Califórnia durante o Porfiriato ${ }^{38}$ ligavam Sonora ao Sudoeste americano e, consequentemente, a todo o mercado norte-americano. Os sonoranos percebiam que estavam bem posicionados para se aproveitar das diferentes vantagens comerciais oferecidas pelo acesso aos mercados nos Estados Unidos. Os Estados Unidos estavam abrindo seu Oeste e seu Sudoeste à agricultura comercial através do Reclamation Act de 1902, que proporcionava uma nova e abundante fonte de financiamento federal para represas e sistemas de irrigação, e havia fortes razóes para se pensar que medidas similares poderiam ser empreendidas para os vales desérticos do México. Em todo o mundo, esses eram dias de um entusiasmo contagiante em relação à maneira extraordinária que "o deserto florescia" com a adição de água na medida em que a potencial irrigação em larga escala possibilitada pela maquinaria do século XX e os avanços da engenharia se tornavam aparentes. O caminho para a riqueza, geográfica e conceitualmente, apontava para o norte, e não para os planaltos da região central do México no sul ${ }^{39}$.

Embora tivesse crescido órfão e na pobreza, Obregón tornara-se um rico produtor rural e empresário antes de 1910. Ele obteve um lucro substancial com a invenção de uma máquina de semear grão-de-bico, comprada por uma firma comercial dos Estados Unidos, e ficou conhecido como "o rei do gráo-de-bico", monopolizando seu comércio ${ }^{40}$. Na condição de maior produtor mundial de grão-de-bico,

\footnotetext{
${ }^{37}$ WRIGHT, Angus. The death of Ramon Gonzalez, op. cit. p. 166-167; HAMILTON, Nora. The limits of State autonomy: post-revolutionary Mexico. Princeton: Princeton University Press, 1982.

${ }^{38}$ Denominação com a qual ficou conhecido o período de 31 anos (1876-1911) em que o México foi governado pelo general Porfírio Díaz. (N.T.)

${ }^{39}$ HART, John Mason. Empire and revolution: the Americans in Mexico since the Civil War. Berkeley: University of California Press, 2002. Especialmente caps. 3, 6, 7, 11 e 12; DWYER, John J. The agrarian divide: the expropriation of American owned rural land in post-revolutionary Mexico. Durham: Duke University Press, 2008.

${ }^{40}$ HALL, Linda. Alvaro Obregón: power and revolution in Mexico: 1911-1920. College Station: Texas A and M Press, 1981.
} 
DESCENDO A MONTANHA E SEGUINDO PARA O NORTE: COMO A DEGRADAÇÃO DO SOLO E OS PESTICIDAS SINTÉTICOS ORIENTARAM A TRAJETÓRIA DA AGRICULTURA MEXICANA AO LONGO DO SÉCULO XX

Angus Wright

Obregón firmou um acordo com Herbert Hoover para abastecer a Associação Americana de Assistência com grãos-de-bico para aliviar a crise de fome na Europa. Calles, que antes de assumir a presidência do México fora um respeitado professor, mas um desastre à frente dos negócios do pai no abastecimento de produtores rurais comerciais, conseguiu usar sua posição na Dinastia de Sonora e, como presidente, de se enriquecer por meio de empresas do agronegócio ${ }^{41}$.

A Dinastia de Sonora tinha pouca simpatia para com o radicalismo agrário de Zapata. Algumas vezes, Obregón e Calles manipularam as demandas dos camponeses como um instrumento para atingir adversários ricos, através da expropriação de suas terras para redistribuição a camponeses sem terra. Essas redistribuiçôes constituíram, no total, cerca de 3\% das terras agricultáveis do México. Os sonoranos opunham-se à existência de propriedades excessivamente grandes, numa dimensão que conduzisse à ineficiência e à falta de zelo empresarial, mas não por princípios de justiça ou de igualdade. Sob a aparência de um governo radical, anticlerical e anti-imperialista, parte substancial do programa da Dinastia de Sonora consistia na promoção do agronegócio norte-americano com a participação de "generais revolucionários” e de outros sócios.

O baixo nível dos recursos econômicos e financeiros do país levou o governo a conferir prioridade à elevação dos níveis de produçấo, incluindo a produção agrícola, e tornou-o relutante para fracionar as propriedades agrícolas, especialmente aquelas relativamente eficientes, orientadas para a produção comercial ${ }^{42}$.

Em 1930, Calles “anunciou que o programa de reforma agrária era um erro, que os peóes não sabiam como usar suas terras, e que a produção de alimentos estava declinando progressivamente”. Calles e o embaixador americano Dwight Morrow concordavam que a reforma agrária já tinha ido longe demais, isto num momento em que ela de fato pouco tinha avançado. Os sonoranos estavam interessados na colonização das terras recém-abertas, sobretudo no norte, o que representava um retorno às políticas do século XIX que tinham encorajado os investimentos mexicanos e estrangeiros nos estados desérticos. ${ }^{43}$ Em 1926, Calles definiu novos mecanismos legais e institucionais para apoiar a colonização de terras tornadas disponíveis para o assentamento, que estavam, em sua maior parte, localizadas em partes do norte e do noroeste que eram irrigadas ou que que logo seriam irrigadas ${ }^{44}$.

Os pressupostos subjacentes da Dinastia de Sonora eram amplamente compartilhados pelas elites mexicanas. O jovem Daniel Cosío Villegas, que viria a se tornar um dos mais proeminentes intelectuais da nação, escreveu em 1924:

A indústria da agricultura em nosso país é deficiente não somente porque os nossos métodos de cultivo são atrasados (...) mas porque o próprio solo é pobre. A fim de que a nossa agricultura venha a ser capaz de satisfazer nossas necessidades (...) serão necessários dispendiosos trabalhos de engenharia, especialmente de irrigação, por toda a nação. Não podemos esperar nada como um presente da Natureza; tudo no México depende da atividade e da engenhosidade do homem. É por essa razão que eu digo que "nós somos economicamente pobres"; porém, mais do que isso, a origem da nossa pobreza econômica é a nossa pobreza natural ${ }^{45}$.

\footnotetext{
${ }^{41}$ BUCHENAU, Jürgen. Plutarco Elías Calles and the Mexican Revolution. Denver: Rowman and Littlefield, 2006.

${ }^{42}$ HAMILTON, Nora. The limits of State autonomy, op. cit. p. 96-97.

${ }^{43}$ HART, John Mason. Empire and revolution, op. cit. Parte II; HAMILTON, Nora. The limits of State autonomy, op. cit. p. 96-97.

${ }^{44}$ BARKIN, David; KING, Timothy. Regional economic develpment: the river basin approach in Mexico. Cambridge: Cambridge University Press, 1970. p. 53.

${ }^{45}$ STAKMAN, E. C. et al. Campaigns against hunger. Cambridge, Massachusetts: Harvard University Press, 1967. p. 2.
} 
DESCENDO A MONTANHA E SEGUINDO PARA O NORTE: COMO A DEGRADAÇÃO DO SOLO E OS PESTICIDAS SINTÉTICOS ORIENTARAM A TRAJETÓRIA DA AGRICULTURA MEXICANA AO LONGO DO SÉCULO XX

Angus Wright

Como Melville observou, a pobreza do solo mexicano foi considerada sua condição original, mais do que uma consequência de séculos de uso inadequado e do impacto específico de animais, tecnologias e objetivos europeus. A internalização dessa atitude entre os intelectuais mexicanos foi um fator relevante para a escolha que o México viria a fazer sobre suas terras, numa oposição a-histórica "homem versus Natureza", que serve como um exemplo soberbo do "alto modernismo" do século XX em ação.

Com o prevalecimento dessas perspectivas, em meio a fatores políticos mais mundanos, não é de se surpreender que Calles - que continuara a controlar indiretamente os presidentes que exerceram o poder depois dele, entre 1928 e 1934 - acreditasse que seria capaz de dar prosseguimento às políticas da Dinastia de Sonora após a eleição presidencial de 1934. No entanto, o candidato designado, Lázaro Cárdenas, que tinha governado o estado centro-ocidental de Michoacán, demonstrou não só ser capaz de pensar por si mesmo, como também de definir um itinerário independente e provocar a ida de Calles para o exílio. Um dos elementos mais importantes do que Cárdenas pensava para o México era o retorno à ideia de uma redistribuição significativa da terra, como estava prevista na Constituição de 1917. Cárdenas expropriou cerca de 49 milhóes de acres de terras, criou milhares de ejidos (concessóes de terras às comunidades) e restaurou um modesto número de terras comunais indígenas, como fora delineado pela facção camponesa ao escrever a Constituição de 1917. Entre um quarto e a metade da população mexicana tornou-se membro de ejidos. Embora com a evolução do ejido houvesse uma tendência a um trabalho mais individualizado em pequenos lotes distribuídos pelos diretores dos ejidos, o governo Cárdenas encorajou a formação de cooperativas de crédito, comercialização e compra de máquinas e ofereceu crédito governamental para os ejidatarios (nome dado aos beneficiários da reforma agrária). Cárdenas também promoveu experimentalmente a coletivização de algumas grandes propriedades rurais, sobretudo as fazendas de algodão de La Laguna, situadas em áreas desérticas no estado nortista de Coahuila, e nos estados vizinhos.

A administração Cárdenas considerava a educação agrícola crucial para o sucesso do programa de reforma agrária. A conservação do solo encontrava-se entre os temas que os agentes governamentais deveriam ensinar aos agricultores. As autoridades procuraram diversas maneiras criativas para promover tanto a cultura quanto a prática da moderna conservação. ${ }^{46}$ Ao mesmo tempo, o governo nacional e os escritores, artistas e intelectuais populares tentaram aprofundar o interesse dos mexicanos por seu passado indígena e pela população indígena remanescente. Embora essas iniciativas tenham sido ridicularizadas por vezes como superficiais e passageiras, uma de suas realizaçôes foi a ressurgência de um modesto grau de interesse por cultivos indígenas e seus métodos agrícolas. ${ }^{47}$

O sério compromisso de Cárdenas em relação à conservação pode ser comparado ao de Franklin Roosevelt. A ênfase na conservação tinha por objetivo melhorar o desempenho da economia e reduzir a pobreza. A conservação do solo ainda era vista como um aspecto da proteção das florestas, como acontecera no passado; novas leis e instituiçóes deram ao governo mais poder para tornar efetiva a conservação florestal. A despeito do foco nas florestas, no entanto, a associação dos programas de conservação de Cárdenas à redistribuição de terras passou a evidenciar mais claramente os elos entre a erosão do solo e questóes de equidade.

Cárdenas estava determinado a erigir o poder do partido dirigente com base no entusiasmo popular. A reforma agrária fazia parte desse seu programa, assim como outras iniciativas que ampliaram a autoridade governamenal - e, por conseguinte, a distribuição de favores - em muitas novas áreas. Seu uso de longas viagens às áreas rurais no interior do país e do poder do rádio e da publicidade na imprensa divulgando as políticas nacionais, bem como sua própria personalidade lhe conferiram uma projeção que estava se tornando a marca dos políticos modernos por toda a parte. A visão de Cárdenas

\footnotetext{
${ }^{46}$ SIMONIAN, Lane. Defending the land of the jaguar, op. cit. cap. 5.

${ }^{47}$ WRIGHT, Angus. The death of Ramon Gonzalez, op. cit. p. 168-171.
} 
DESCENDO A MONTANHA E SEGUINDO PARA O NORTE: COMO A DEGRADAÇÃO DO SOLO E OS PESTICIDAS SINTÉTICOS ORIENTARAM A TRAJETÓRIA DA AGRICULTURA MEXICANA AO LONGO DO SÉCULO XX

Angus Wright

era claramente nacionalista; o legado mais duradouro e concreto dessa perspectiva foi a nacionalização que promoveu da importante indústria petrolífera mexicana. Essa orientação provocou confrontos com os Estados Unidos e a Inglaterra, os países de origem dos principais proprietários das instalaçóes petrolíferas expropriadas. Alguns assessores do governo dos Estados Unidos chegaram a defender a invasão armada do México, ainda que, na atmosfera da Política da Boa Vizinhança, que buscava aliados entre os países latino-americanos na guerra que se aproximava com a Alemanha e a Itália, as cabeças mais sensatas tenham prevalecido.

Embora uma guerra entre México e Estados Unidos tenha sido descartada, facçóes políticas nos dois países começaram a planejar o enfraquecimento do nacionalismo populista de Cárdenas nas eleiçôes presidenciais marcadas para 1940. Os líderes empresariais e os grandes proprietários rurais temiam um sério enfraquecimento dos interesses e da influência do capital privado e consideravam o pleito de 1940 um teste crucial à sua capacidade de sobrevivência. Cárdenas tornara o partido dirigente muito mais popular e poderoso, e se opor à sua dominação não era visto como uma opção. A batalha seria pelo controle interno do partido. As facçôes conservadoras conseguiram se impor e escolheram Manuel Ávila Camacho como o candidato presidencial e ele, como era de se esperar, foi eleito para o cargo ${ }^{48}$.

Em seu discurso de posse, Ávila Camacho elogiou "a energia vital da iniciativa privada" e prometeu "aumentar a proteção dada às propriedades agrícolas, não somente defendendo aquelas que existem, mas também formando novas propriedades nas vastas regiôes ainda não cultivadas”. A agricultura não seria vista como um meio de se atingir uma maior igualdade, mas sim como a base da "grandeza industrial" ${ }^{\prime 9}$. Começando com a administração Ávila Camacho e avançando pelo restante do século $\mathrm{XX}$, a reforma agrária, nas ocasiōes em que amplas superfícies cultiváveis foram distribuídas, era quase sempre direcionada sobretudo como uma forma de reduzir a instabilidade rural em certas regióes e reduzir o movimento migratório para as cidades. A maior parte da terra era apenas marginalmente produtiva, mas parcelas significativas foram importantes para a restauração das terras de florestas para as comunidades indígenas. A despeito de redistribuiçôes ocasionais de terra terem continuado, a reforma agrária não seria mais vista, como era considerada por Cárdenas, como um instrumento primordial para atingir o desenvolvimento agrícola e econômico da nação.

Distribuiçôes de terras agricultáveis numa escala significativa ocorreram principalmente nas áreas recentemente irrigadas, abertas nos desertos do norte do país, que contaram com o financiamento para a construção de barragens e canais por parte do governo mexicano e, mais tarde, do Banco Mundial. As distribuiçôes de terras irrigadas, de boa qualidade, destinaram-se principalmente àqueles que a Constituição de 1917 definira como pequeños proprietarios (pequenos proprietários privados e não ejidos e ejiditarios), ou terminaram sob o controle destes. Os "pequenos proprietários", muitos dos quais viriam a possuir vastas extensóes de terras, constituíam a pedra angular para a expansão da agricultura empresarial comercial, com base precisamente no modelo delineado pela Dinastia de Sonora. O capital estrangeiro participaria pesadamente no financiamento de muitas dessas operaçóes.

Nos vales do Culiacán e Fuerte, em Sinaloa e Sonora, os ejidos ganharam direitos à terra durante o governo Cárdenas ou mais tarde, em uns poucos casos. Esses ejidos, contudo, seriam submetidos à sistemática corrupção das intençôes da reforma agrária, algumas vezes mediante o arrendamento ou a aquisição ilegal de terra ejidal, envolvendo o uso do Estado e da violência privada contra os agricultores recalcitrantes (o que, por exemplo, continuou a ocorrer no Fuerte Vale até os anos 1970). Ejidos genuínos foram às vezes deslocados por empresários da agricultura comercial que operavam sob a aparência

\footnotetext{
${ }^{48}$ HAMILTON, Nora. The limits of State autonomy, op. cit. p. 216-240.

${ }^{49}$ Citado em ALCÂNTARA, Cynthia Hewitt de. Modernizing Mexican agriculture: socio-economic implications of technological change, 1940-1970. Genebra: United Nations Research in Social Development, 1976. p. 21-22.
} 
DESCENDO A MONTANHA E SEGUINDO PARA O NORTE: COMO A DEGRADAÇÃO DO SOLO E OS PESTICIDAS SINTÉTICOS ORIENTARAM A TRAJETÓRIA DA AGRICULTURA MEXICANA AO LONGO DO SÉCULO XX

Angus Wright

legal de uma concessão de ejido ${ }^{50}$. A corrupção dos ejidos nesses vales do norte se revelaria crucial para a história do desenvolvimento agrícola do México na era pós-Segunda Guerra Mundial.

\section{O pacote da Revolução Verde mexicana}

Sentado ao lado de Ávila Camacho na cerimônia de sua posse estava o recém-eleito vice-presidente dos Estados Unidos, Henry Wallace, anteriormente secretário de Agricultura de Roosevelt. Wallace herdara o legado de seu pai como plantador de milho e dono de uma das maiores empresas de sementes do mundo. Embora fosse conhecido nos Estados Unidos como um político de esquerda, seu papel na restauração das forças conservadoras no México mostrou outro lado de Wallace. Posteriormente, ele comentou que não tinha feito nada mais do que ajudar a evitar a revolução no México. A importância que conferiu a esse papel explicava por que Wallace passava tantas semanas no México, quando acabara de ser reeleito vice-presidente dos Estados Unidos. Seja o que for que Wallace tenha feito nessas semanas, no longo prazo, sua obra mais importante no México foi ajudar a negociar um programa de pesquisa que apoiaria a nova ênfase do país à produtividade agrícola, em oposição à reforma agrária ${ }^{51}$.

A eleição de Ávila Camacho colocou o governo do México no caminho de uma política agrícola que reafirmava a visão inicialmente proposta pela Dinastia de Sonora, mas que se tornou mundialmente conhecida como a Revolução Verde. A Fundação Rockefeller, que começara a ampliar suas preocupaçóes para além dos programas voltados para o bem-estar das crianças mexicanas dos anos 1920, forneceu financiamento e liderança decisivos para um programa de pesquisa que visava incrementar a produtividade agrícola no país, com um olho na possibilidade de se reproduzirem os sucessos registrados no México no resto do mundo tropical e subtropical ${ }^{52}$. Com a aprovação do programa pelo Departamento de Agricultura norte-americano, pela Fundação Rockefeller e pelo governo mexicano, os trabalhos começaram em 1941 e pode-se dizer que continuam até os dias de hoje no México, bem como no resto do mundo, com várias formas de financiamento e direção.

O primeiro passo era uma viagem de estudos a ser empreendida por proeminentes cientistas agrícolas dos Estados Unidos, a fim de determinar a natureza dos problemas e recomendar estratégias de pesquisa destinadas a solucioná-los. A Fundação recrutou uma equipe liderada por Richard Branfield, da Universidade de Cornell, Paul C. Manglesdorf, da Universidade de Harvard, e Elvin Stakman, da Universidade de Minnesota. Essa "Comissão de Reconhecimento" começou sua viagem de cinco meses em julho de 1941. A história da jornada da Comissão e sua perspectiva são contadas no livro Campaigns against hunger, escrito duas décadas mais tarde, quando a Fundação Rockefeller e o governo norte-americano estavam promovendo com entusiasmo na Índia, no Paquistão e em boa parte do resto do mundo o suposto sucesso que tinham alcançado no México. Os cientistas da comissão mostraram interesse pelos mexicanos e certo apreço por sua cultura e inteligência, mas o que prevaleceu foi um paternalismo presunçoso e autocongratulatório, baseado na suposição de que seriam cientistas como os próprios autores que teriam todas as chaves para acabar com a fome e trazer prosperidade ao México e a todas as naçôes mais pobres. $\mathrm{O}$ fato de os três cientistas da comissão terem sido treinados em ciências naturais, sem praticamente nenhuma contribuição de cientistas sociais ou historiadores, refletia a supo-

\footnotetext{
${ }^{50}$ Relatos detalhados de como isso era feito podem ser encontrados em Cepal. Economía campesina y agricultura empresarial. Cidade do México: Siglo XXI, 1982; e MARES, David. Penetrating the international market: theoretical considerations and a Mexican case study. Nova York: Columbia University Press, 1987.

${ }^{51}$ WRIGHT, Angus. The death of Ramon Gonzalez, op. cit. p. 172-177.

${ }^{52}$ FARLEY, John E. To cast out disease: a history of the International Health Division of the Rockefeller Foundation (19131951). Oxford: Oxford University Press, 2003; PERKINS, John H. Geopolitics and the Green Revolution: wheat, genes, and the Cold War. Oxford: Oxford University Press, 1997; WRIGHT, Angus. The death of Ramon Gonzalez, op. cit.
} 
DESCENDO A MONTANHA E SEGUINDO PARA O NORTE: COMO A DEGRADAÇÃO DO SOLO E OS PESTICIDAS SINTÉTICOS ORIENTARAM A TRAJETÓRIA DA AGRICULTURA MEXICANA AO LONGO DO SÉCULO XX

$$
\text { Angus Wright }
$$

sição inquestionável de que todas as soluçóes para a fome deveriam ser encontradas na tecnologia. Não houve nenhuma tentativa séria para se analisar o programa da reforma agrária ${ }^{53}$.

As recomendaçóes da Comissão de Reconhecimento começavam destacando a importância da melhoria da "gestão do solo e das práticas de cultivo". Era de se esperar que o que se seguiria daí seria um esforço para melhorar a gestão do solo e as práticas de preparo do solo nas terras agricultáveis então sob cultivo, mas não foi essa a lógica. A melhor gestão do solo seria assegurada enquanto resultado de variedades melhoradas a serem desenvolvidas por criadores de plantas e animais, pela ampliação dos trabalhos de irrigaçáo em larga escala, e pelo "controle mais racional e efetivo das doenças das plantas e das pragas de insetos" 54 . Embora os cientistas norte-americanos tenham reconhecido a grande inventividade das chinampas, concluíram que os mexicanos jamais poderiam esperar ter de novo essa agricultura produtiva. Não foi conferida, praticamente, nenhuma atenção efetiva a outras práticas tradicionais mexicanas para a gestáo do solo, e relativamente pouco estudo foi desenvolvido para o que deveria ser feito especificamente nas superfícies cultiváveis existentes. Considerava-se que os solos mexicanos eram ricos em muitos nutrientes, mas cronicamente pobres em nitrogênio. Não houve nenhuma discussão de como os mexicanos haviam lidado com esse problema no passado, mas apenas desesperança sobre o que poderia ser realizado nas terras entáo cultivadas e degradadas. Em certa medida, o processo Haber-Bosch e a disponibilidade de fertilizantes à base de amônia, produzidos comercialmente, eram a solução. Variedades "melhoradas" de sementes e cultivos seriam planejadas para maximizar a absorção de nitrogênio. Isso requereria a liberação de água, abundante e confiável, o que só poderia ser obtido por uma considerável expansão da superfície de cultivo irrigada através de represas que forneceriam água àquelas áreas então consideradas fronteiras virtualmente vazias de terras planas e desérticas. Era a superfície de cultivo recém-irrigada que importava, e não a melhor prática na terra existente ${ }^{55}$. Os cientistas estavam orgulhosamente recomendando uma abordagem ousada e transformadora. Foi apresentada como a desejada alternativa a outra escolha possível, também ousada e transformadora: concentrar esforços políticos e científicos mais intensamente na proteção, no melhoramento e na restauração de terras que estavam sendo trabalhadas pelos beneficiários da reforma agrária e por outros. A comissão preferiu, em vez disso, apostar seu prestígio na expansão para novas terras irrigadas e nas tecnologias.

Suas recomendações representaram uma notável concordância de visôes — e isso certamente não foi uma coincidência. Em 1941, Ávila Camacho, em discurso à nação, afirmou que

O futuro da agricultura reside nas terras férteis da costa. Uma marcha para o mar aliviará a congestão em nosso planalto central, onde as terras cansadas devem ser dedicadas a cultivos que a política colonial recusou, resultando daí que a tradicional cultura do milho das populaçóes indígenas continuou a ser dominante. A fertilidade das planícies costeiras tornará antieconômico o plantio de muitos produtos no planalto central. Porém, a marcha para o mar requer (...) medidas sanitárias e de saúde, a abertura de comunicaçóes e a recuperação e drenagem de pântanos, e, para tornar tais projetos possíveis, o dispêndio de grandes somas de dinheiro. Será necessário organizar um novo tipo de agricultura tropical, que, devido à própria natureza da sua produção, não poderá ser implementado em pequena escala ${ }^{56}$.

Dada como receita e presságio, não se poderia ter uma visão mais profética do futuro da Revolução Verde no México e em outros lugares. Vale notar também que, ao contrário das continuadas negativas dos proponentes da Revolução Verde dos anos 1940 até o presente, a lógica por detrás de sua criação era

\footnotetext{
53 STAKMAN, E. C. et al. Campaigns against hunger. Cambridge, Massachusetts: Belknap Press, 1967.

${ }^{54}$ Ibidem, p. 33.

55 Ibidem, caps. 1,8 e 9.

${ }^{56}$ Citado em BARKIN, David; KING, Timothy. Regional economic development, op. cit. p. 54.
} 
DESCENDO A MONTANHA E SEGUINDO PARA O NORTE: COMO A DEGRADAÇÃO DO SOLO E OS PESTICIDAS SINTÉTICOS ORIENTARAM A TRAJETÓRIA DA AGRICULTURA MEXICANA AO LONGO DO SÉCULO XX

Angus Wright

vista como uma clara rejeição da agricultura em pequena escala ${ }^{57}$. Era evidente a direção que o processo estava seguindo.

Na segunda metade dos anos 1940, todo esse planejamento começou a dar frutos de maneiras muito diferentes. O governo mexicano baseou boa parte da sua estratégia de desenvolvimento nas Comissóes de Bacias Fluviais - tendo como modelo, em grande medida, a Tennessee Valley Authority —, projetadas para fornecer irrigação para a agricultura, terra para os assentamentos e eletricidade para a indústria. O sucesso dessas Comissões variou muito. As mais bem-sucedidas (tendo como medida de sucesso diversos indicadores econômicos e de bem-estar) foram aquelas localizadas no norte do país, especialmente no Pacífico Norte — os estados de Sonora, Sinaloa, Baixa Califórnia (norte e sul) e Nayarít. Por volta de 1960, o Pacífico Norte representava 43\% das iniciativas de irrigação em larga escala do governo mexicano em termos de superfície de cultivo. Os estados do norte em seu conjunto representaram mais de três quartos do total. $\mathrm{O}$ único outro lugar comparável localizava-se na região central do país, reunindo 14,5\% dos esforços do governo, o que se explica somente por essa ser uma das mais importantes e permanentes regiōes agrícolas do México: o Bajío de Guanajuato, Querétaro e estados adjacentes. Os novos estados irrigados tiveram rápido crescimento em termos de investimentos, produção agrícola e crescimento industrial durante esse período, proporcionando uma notável melhora na renda per capita e no desempenho em todos os indicadores de bem-estar ${ }^{58}$. Sem contar os custos muito óbvios e ocultos, a Revolução Verde representou claramente, pelo menos no curto prazo, um sucesso de produção, embora já tenha sido convincentemente demonstrado que cerca de dois terços ou mais dos ganhos poderiam ter sido alcançados na mesma superfície de cultivo irrigada, lançando-se mão de tipos de lavouras tradicionais menos dependentes de agroquímicos sintéticos do que aqueles novos que se encontravam na base da Revolução Verde. Não foi estimado que resultados poderiam ter sido alcançados caso o foco tivesse sido direcionado para a inovação e o desenvolvimento das terras já disponíveis ${ }^{59}$.

O governo mexicano e o programa de pesquisa da Rockefeller buscavam resolver, primordialmente, os problemas colocados pelo solo do país e sua contínua degradação não através da restauração ou da conservação dos solos nas regiốes tradicionais do México, mas essencialmente através da expansão da fronteira agrícola, baseada na irrigação em larga escala. A fronteira nem de longe estava vazia; a agricultura vinha sendo praticada há milênios na maior parte daquilo que era denominado "novas terras" ${ }^{\circ 0}$. $\mathrm{O}$ que era novo eram a tecnologia e o controle. Uma evidência dessa orientaçáo foi o fato de que quando Ávila Camacho criou o primeiro Departamento de Conservação do Solo, em 1942, o órgão foi colocado sob a autoridade da Comissão Nacional de Irrigação, em vez de ficar subordinado à Secretaria de Agricultura, como era de se esperar ${ }^{61}$. O órgão foi transferido para a Agricultura em 1946, e a Secretaria de Agricultura foi logo rebatizada com o nome de Secretaria de Agricultura e Recursos Hídricos (Secretaría de Agricultura y Recursos Hidráulicos — SARH). Nos anos 1980, os empregados subalternos se queixavam frequentemente de que eram os "recursos hídricos" e não a "agricultura" que predominavam

\footnotetext{
${ }^{57}$ A aplicabilidade da Revolução Verde à agricultura de pequenos proprietários era e continua sendo um tema de intensa controvérsia e objeto de uma vasta literatura. No México, a controvérsia se centra no Projeto Puebla, financiado pela Fundação Rockefeller e planejado para demonstrar que a Revolução Verde era apropriada aos pequenos agricultores. Ver JENNINGS, Bruce H. Foundations of international agricultural research: science and politics in Mexican agriculture. Boulder, Colorado: Westview, 1988. Ver também, WRIGHT, Angus. The death of Ramon Gonzalez, op. cit. e PERKINS, John H. Geopolitics and the Green Revolution, op. cit.

58 BARKIN, David; KING, Timothy. Regional economic develpment, op. cit. p. 54-65.

${ }^{59}$ YATES, Paul Lamartine. Mexico's agriculture dilemma. Tucson: University of Arizona, 1981.

${ }^{60}$ Para um excelente panorama das práticas territoriais no deserto do nordeste do Méxco, em meados do século XIX, ver RADDING, Cynthia. Wandering peoples: colonialism, ethnic spaces, and ecological frontiers in Northwestern México, 1700-1850. Durham; Londres: Duke University Press, 1997; e DOOLITTLE, William E. Cultivated landscapes of native North America, op. cit.

${ }^{61}$ SIMONIAN, Lane. Defending the land of the jaguar, op. cit. p. 113.
} 
DESCENDO A MONTANHA E SEGUINDO PARA O NORTE: COMO A DEGRADAÇÃO DO SOLO E OS PESTICIDAS SINTÉTICOS ORIENTARAM A TRAJETÓRIA DA AGRICULTURA MEXICANA AO LONGO DO SÉCULO XX

Angus Wright

na burocracia da secretaria. Lane Simonian registra a maneira pela qual os sucessivos presidentes clamavam que a conservação do solo era uma causa urgente, citando estatísticas alarmantes, sem jamais assegurar recursos suficientes para esse fim. Funcionários dedicados do serviço para conservação do solo trabalhavam em todo o México, mas eles estavam remando contra uma maré tanto de forças naturais quanto de políticas governamentais, que tinham outras prioridades ${ }^{62}$.

\section{A revolução dos pesticidas}

À medida que crescia a área irrigada, também se multiplicavam as novas variedades de sementes desenvolvidas pelas equipes de pesquisa da Revolução Verde, sendo os sucessos mais celebrados aqueles provenientes de um novo centro de pesquisa, situado nas proximidades da muito apropriadamente chamada Ciudad Obregón, em Sonora. Essas novas variedades só podiam ser bem-sucedidas, insistiam os pesquisadores, quando fosse usado o "pacote" completo. Eram concebidas para absorver e converter mais nitrogênio em grãos; porém, uma maior quantidade de nitrogênio seria tóxico para as plantas, se não fosse liberada com água adequada, aplicada nos momentos certos. Na sequência, havia a expectativa de que a massa maior de material de plantas produzido mais densamente num solo mais úmido e num ambiente de campo atrairia mais doenças de plantas e pragas de insetos. Isso requereria um uso mais intenso dos pesticidas sintéticos que acabavam de ser desenvolvidos ${ }^{63}$. A agricultura comercial tornou-se profundamente dependente do emprego regular de fertilizantes e pesticidas, enquanto na agricultura de subsistência e no mercado local a dependência dos agricultores ignorantes em relação aos agroquímicos era pontual, limitada, numa considerável medida, pelos custos elevados dos químicos. As escolas de agricultura e as agências de extensão financiadas pelo governo gastaram uma parcela significativa de seus esforços trabalhando com agricultores e consultores privados para manter listas de fórmulas recomendadas para a aplicação de fertilizantes e pesticidas em determinadas regióes e culturas.

As sementes e o pacote químico requeriam, como a nova estratégia de desenvolvimento agrícola de Ávila Camacho havia previsto, muito dinheiro. Esse dinheiro incluía muito mais do que os trabalhos de irrigação financiados pelos bancos de desenvolvimento multilaterais e pelo governo mexicano. As novas sementes e os agroquímicos, fertilizantes e pesticidas, eram caros. Os cultivos de grãos da Revolução Verde raramente podiam ser produzidos competitivamente, à exceção dos cultivados e colhidos por máquinas custosas, que só poderiam compensar se usadas em faixas relativamente extensas de terra. Tudo isso significava que o acesso ao crédito tornou-se mais fundamental e, sobretudo nos ambientes relativamente arriscados dos países mais pobres, o crédito era e é caro. O governo mexicano ofereceu crédito rural abundante por cerca de três décadas (aproximadamente da década de 1950 até os primeiros anos da década de 1980), mas ele era oferecido de forma seletiva, sem consistência, e frequentemente usado como um meio de exercer influência, tanto quanto para objetivos de produção. Nos anos 1980, agricultores comercialmente bem-sucedidos dependiam cada vez mais pesadamente do crédito comercial, a maior parte do qual estrangeiro; nesse momento, a dependência deles para com o crédito privado tornou-se completa com a virtual eliminação dos programas de crédito rural patrocinados pelo governo.

Quando os consultores agrícolas e os agricultores colocavam o valor dos fertilizantes e pesticidas em dúvida, os bancos privados e os bancos públicos normalmente evocavam cláusulas garantindo a permanência de regimes de produção projetados para assegurar tanto empréstimos vultosos quanto seus pagamentos mediante o uso obrigatório de agroquímicos. Os agricultores também trabalhavam sob o regime de produção contratada, segundo a qual os custos de produção eram antecipados por uma

${ }^{62}$ SIMONIAN, Lane. Defending the land of the jaguar, op. cit. cap. 5.

${ }^{63}$ STAKMAN, E. C. et al. Campaigns against hunger, op. cit. Especialmente caps. 5 e 9. 
DESCENDO A MONTANHA E SEGUINDO PARA O NORTE: COMO A DEGRADAÇÃO DO SOLO E OS PESTICIDAS SINTÉTICOS ORIENTARAM A TRAJETÓRIA DA AGRICULTURA MEXICANA AO LONGO DO SÉCULO XX

Angus Wright

empresa de promoçáo, em troca da entrega das colheitas — essas ações normalmente envolviam recomendaçôes ou determinaçôes para o emprego de químicos.

No México, o nacionalismo de Cárdenas foi rapidamente posto a serviço do modelo produtivista de Ávila Camacho, da Fundação Rockefeller e do governo dos Estados Unidos. A maior parte dos defensivos agrícolas era fabricada usando petróleo e/ou gás natural como matéria-prima. A Pemex, a empresa petrolífera nacionalizada, tornou-se uma importante fabricante de defensivos agrícolas através de sua subsidiária, a Fertempox. Nos anos 1980, a Fertempox tornou-se a maior produtora e maior exportadora mundial de DDT, em uma conjuntura em que a maioria dos países industriais havia virtualmente proibido seu uso. A Fertempox produziu também um conjunto de outros pesticidas. Na década de 1980, às vezes a Fertempox fornecia gratuitamente fertilizantes e pesticidas aos produtores rurais em nome do desenvolvimento agrícola. $\mathrm{O}$ asfaltamento com materiais baratos provenientes da Pemex permitiu a abertura de estradas unindo as áreas produtoras ao mercado e que logo atravessaram as regióes agrícolas mais prósperas. O combustível barato manteve os caminhóes e os tratores em movimento ${ }^{64}$. A maior parte do investimento público na agricultura era justificada pelo argumento de que a independência política e econômica do México estava ligada à autossuficiência na produção dos grãos básicos. Esse argumento só foi abandonado com a liberalização do comércio que foi estabelecida durante os anos 1990, quando o mercado mexicano foi atirado à competição internacional ${ }^{65}$.

Com o pesado investimento público em sistemas de irrigação, estradas, comunicações e outras infraestruturas, e com o investimento privado na agricultura comercial, empresas e produtores agrícolas procuraram maneiras de maximizar seus investimentos. A venda de grandes quantidades de grãos que eram, muitas vezes, produzidos mais barato no exterior e tinham margens de lucro muito estreitas no melhor dos cenários - começou a parecer menos atraente a muitos produtores rurais e a seus credores. Nos anos 1960, eles começaram a perceber a existência de um mercado potencial cada vez maior para frutas e vegetais tropicais e fora de estação nos Estados Unidos e na Europa. A partir do programa do governo mexicano para assegurar um estoque adequado de grãos básicos para a população mexicana, tudo o que era necessário - água, terra, produtos químicos, estradas, comunicaçôes, crédito baratos, força de trabalho estreitamente controlada e barata — estava disponível para deslocar uma considerável porção de terras que produziam grãos para cultivos mais valiosos. Esses poderiam ser vendidos para consumidores com um apetite virtualmente insaciável por alimentos exóticos, fora da estação, e com mais dinheiro do que o que se podia encontrar no mercado doméstico. $O$ vale do Culiacán, no estado de Sinaloa, no litoral Pacífico norte, foi o mais bem-sucedido no aproveitamento dessa oportunidade. Boas estradas e ferrovias estendiam-se por $965 \mathrm{~km}$ na direção norte, até Nogales, no Arizona. Dali, os vegetais podiam ser enviados para os mercados dos Estados Unidos e do Canadá. Nos primeiros anos da década de 1980, o vale do Culiacán já estava fornecendo, de forma consistente, um terço de todos os vegetais "de verão" (tomates, pepinos, pimentas, beringelas, pimentôes etc.) vendidos entre dezembro e maio nos Estados Unidos. Quando as colheitas na Flórida ficavam abaixo das expectativas, a participação do Culiacán podia chegar, às vezes, a dois terços. De acordo com as disposiçóes da Constituição de 1917, aplicáveis até a emenda constitucional de 1992, essas propriedades rurais pertenciam, pelo menos nominalmente, a mexicanos, mas $90 \%$ do financiamento foram provenientes dos Estados Unidos e, com isso, boa parte do controle sobre a produção e a comercialização passou para suas mãos. Outros vales irrigados dos estados do norte do México aumentaram o fluxo de frutos, vegetais e, eventualmente, mesmo de vinhos, de alto valor, para os mercados dos Estados Unidos, do Canadá e dos centros urbanos mexicanos. Mais para o sul, áreas agrícolas como Apatzingán e Michoacán experimentaram o mesmo

${ }^{64}$ FERTEMPOX. Plan de desarrollo de Fertempox en la producción, formulación y comercialización de pesticidas. Cidade do México: Gerencia General de Planeación, 1981.

${ }^{65}$ WRIGHT, Angus. The death of Ramon Gonzalez, op. cit. caps. 6 a 9. 
DESCENDO A MONTANHA E SEGUINDO PARA O NORTE: COMO A DEGRADAÇÃO DO SOLO E OS PESTICIDAS SINTÉTICOS ORIENTARAM A TRAJETÓRIA DA AGRICULTURA MEXICANA AO LONGO DO SÉCULO XX

Angus Wright

tipo de boom nas atividades ligadas à horticultura e voltadas principalmente para a exportação. No Bajío, a produção de grãos e a pecuária continuaram a predominar como acontecera por séculos, mas era crescente a exportação de produtos hortigranjeiros, incluindo, por exemplo, a produção de morangos do ex-presidente mexicano Vicente Fox ${ }^{66}$.

Recentemente, culturas tradicionais - como a cana-de-açúcar na parte sul do estado de Puebla, tabaco em Nayarít e algodão em Coahuila — tornaram-se dependentes de pesticidas e fertilizantes sintéticos. Embora raramente com a mesma intensidade das atividades hortigranjeiras em larga escala de Sinaloa ou dos campos de algodáo de La Laguna, alguns pequenos agricultores também se tornaram altamente dependentes de pesticidas. Seu uso menos frequente deve-se, normalmente, mais ao custo do que às precauções.

Nos anos 1980 ficou claro que muitos mexicanos e a maior parte das melhores terras do México estavam começando a pagar um preço elevado por essa enorme expansão da agricultura comercial, dependente de pesticidas sintéticos. Estudos realizados no vale do Culiacán, desde os anos 1970 até pelo menos os primeiros anos do século XXI, mostraram que o uso descontrolado de pesticidas provocou uma séria contaminação de cursos d'água e um ataque sistemático à saúde dos trabalhadores agrícolas e aos moradores das áreas rurais.

Meu próprio estudo de campo — conduzido no inverno de 1983-1984 e que compreendeu visitas continuadas até 1989 - constatou que combinaçóes altamente tóxicas de pesticidas estavam sendo usadas cerca de cinquenta vezes num período de dez meses. Desde janeiro até maio, os plantadores aplicaram com grande frequência uma combinação de inseticida com fungicida duas vezes por semana. Os agricultores e os agrônomos que os supervisionavam ignoraram rotineiramente todas as precauçóes com segurança sugeridas pela indústria destinadas a proteger os trabalhadores agrícolas, os moradores das áreas rurais e o meio ambiente, bem como a legislaçáo nacional e os padróes internacionais. Os professores e pesquisadores da universidade local relataram que estavam com muito medo de perder seus empregos ou de sofrer represálias violentas por estudarem o problema ou por se referirem abertamente a ele.

Os trabalhadores agrícolas enfrentaram uma série de ameaças ao seu bem-estar e ao de suas famílias. Eles foram vítimas, com frequência, de envenenamentos agudos por pesticidas, que os levaram, algumas vezes, a serem tratados em clínicas locais. Algumas vezes, porém, eles preferiam não receber tratamento por medo de serem despedidos. Os médicos locais atenderam trabalhadores agrícolas que acabaram morrendo por causa de exposição a pesticidas e um número muito maior que foi vítima de doenças causadas por pesticidas. A maioria dos médicos e enfermeiros não fora adequadamente treinada para reconhecer ou tratar o envenenamento por pesticida. Os trabalhadores usavam pulverizadores costais, que muitas vezes vazavam pesticidas contendo toxinas extremamente perigosas ao sistema nervoso quando entram em contato com a pele. Eles eram convocados para trabalhar nos campos durante e imediatamente após a aplicação de combinações altamente tóxicas. Aviôes que aplicavam pesticidas algumas vezes os lançavam diretamente sobre trabalhadores rurais, incluindo mulheres e crianças. Famílias inteiras de trabalhadores viviam nas proximidades dos campos, em choupanas abertas, destinadas à criação de aves como galinheiros, o que inevitavelmente permitia que as aplicaçóes de pesticida no chão e no ar se espalhassem, contaminando a área de convivência, as roupas de cama e os alimentos. Os tambores de pesticidas eram normalmente usados para beber água e armazenar comida; ademais, as pessoas costumavam tomar banho nos canais de irrigação contaminados.

Os trabalhadores tinham ideias extremamente diversas sobre o problema. Alguns compreendiam bem os perigos, mas achavam que não havia nada que pudesse ser feito a respeito porque precisavam do

\footnotetext{
${ }^{66}$ Essa página e as seguintes são baseadas em WRIGHT, Angus. The death of Ramon Gonzalez, op. cit. Para políticas, teoria e suas implicaçôes, ver, sobretudo, os capítulos de 6 a 9 e o posfácio; para o trabalho de campo, ver a introdução, os capítulos de 1 a 4, e o posfácio.
} 
DESCENDO A MONTANHA E SEGUINDO PARA O NORTE: COMO A DEGRADAÇÃO DO SOLO E OS PESTICIDAS SINTÉTICOS ORIENTARAM A TRAJETÓRIA DA AGRICULTURA MEXICANA AO LONGO DO SÉCULO XX

$$
\text { Angus Wright }
$$

trabalho para sobreviver. Muitos tinham um conhecimento parcial da natureza do problema. Alguns se referiam aos pesticidas como "remédios para as plantas" e acreditavam que esses "remédios" também seriam bons para as pessoas. O fato é que a maioria dos trabalhadores agrícolas sofria de muitas outras doenças - as doenças gastrointestinais e a tuberculose eram comuns —, o que complicava ainda mais o problema. Um médico que trabalhava na área relatou que todos os pacientes que entravam em seu consultório eram rotineiramente testados para anemia e que ele nunca encontrou nenhum trabalhador que não tivesse essa doença. Além do mais, os sintomas de envenenamento por pesticida são facilmente confundidos com os sintomas de muitas outras doenças, o que significa que as consequências do envenenamento por pesticida tendiam a ser mais graves quando combinadas com outros problemas de saúde.

As equipes de trabalhadores normalmente incluíam mulheres, algumas delas grávidas, e quase sempre crianças, que se sabia, desde antes dos anos 1980, serem especialmente sujeitas aos danos causados pelo uso dos pesticidas. Toxicologistas já reconheciam que os danos potenciais incluíam doenças muito sérias e até mesmo a morte. Em 1983, três mulheres mixtecas que trabalhavam nos campos do vale do Culiacán morreram por exposição a pesticidas, e ao mesmo tempo abortaram os fetos que elas não sabiam que estavam carregando. Hoje sabemos que o dano permanente aos trabalhadores, mas sobretudo às crianças e às mulheres grávidas, é muito mais sério, mais complicado e algumas vezes mais sutil do que a maioria dos especialistas pensava nos anos 1980. O conhecimento toxicológico atual nos permite supor que um número significativo de trabalhadores agrícolas trabalhando sob as condiçóes encontradas no Culiacán e em todo o México, e também em todo o mundo, seja vítima de uma variedade de problemas físicos e mentais que não foram, e provavelmente nunca serão, diagnosticados como consequência da exposição a pesticidas ${ }^{67}$.

O estudo de campo de Culliacán revelou que os professores universitários de agronomia, agentes de extensão e funcionários do controle estavam sistematicamente mal informados ou eram desonestos a respeito dos tipos e das quantidades de pesticidas aplicados, conforme foi observado em centenas de aplicações no campo. Não podemos saber se as condições melhoraram ao longo das últimas décadas porque os agricultores tornaram praticamente impossível entrar nos campos e realizar estudos adequados sobre o uso de pesticidas, desde quando os resultados dos estudos dos anos 1980 e do começo dos anos 1990 foram levados ao conhecimento público. A insidiosa violência usada no comércio de drogas e no controle da força de trabalho na região também foi usada para intimidar pesquisadores que desejavam levar adiante suas investigaçóes, mesmo quando estavam trabalhando sob a proteção de acordos internacionais firmados entre o México e os Estados Unidos. Somos obrigados a nos basear em evidências menos diretas. Por exemplo, biólogos contratados pela indústria do camarão, atividade que se expandiu nas lagoas costeiras nos anos 1990, estudaram o escoamento dos campos do Culiacán por diversos anos e encontraram níveis consistentemente elevados de contaminação dos mesmos pesticidas geralmente usados na década de 1980. Entrevistas com trabalhadores rurais revelam o que parece ser melhorias marginais nas condiçôes e no treinamento, mas, ao mesmo tempo, deixam claro que eles ainda carecem de conhecimento suficiente para avaliar, de forma consistente, os perigos que enfrentam. Em algumas regiôes, como as plantações de fumo de Nayarít, a observação direta recente e o estudo sistemático mostram que as terríveis condiçôes encontradas no vale do Culiacán nos anos 1980 ainda prevalecem $^{68}$. No Fuerte Vale, estudos sobre a exposição de crianças a pesticidas revelaram problemas evidentes de desenvolvimento mental e físico que parecem estar relacionados à exposição onipresente $\mathrm{e}$

\footnotetext{
${ }^{67}$ WRIGHT, Angus. The death of Ramon Gonzalez, op. cit. Posfácio.

${ }^{68}$ DÍAZ ROMO, Patricia; SALINAS ÁLVAREZ, Samuel. Plaguicidas, tabaco, y salud: el caso de los jornaleros huicholes, jornaleros mestizos y ejiditarios en Nayarít, México. Oaxaca: Proyecto Huicholes y Plaguicidas, 2002; ver também o vídeo Huichols and pesticides, disponível em: <www.huicholesyplaguicidas.org> e em <www.panna.org>, e que também está disponível em espanhol e em doze línguas indígenas do México.
} 
DESCENDO A MONTANHA E SEGUINDO PARA O NORTE: COMO A DEGRADAÇÃO DO SOLO E OS PESTICIDAS SINTÉTICOS ORIENTARAM A TRAJETÓRIA DA AGRICULTURA MEXICANA AO LONGO DO SÉCULO XX

Angus Wright

difusa a pesticidas mesmo em ambientes em que são empregados de forma extensiva, mas onde não há notícias de incidentes de envenenamento agudo por parte das crianças ${ }^{69}$.

O problema da exposição ambiental generalizada a pesticidas, bem como os sintomas agudos que surgem diretamente após a exposição, são exacerbados pelo fato de que os pesticidas sintéticos foram intensamente usados na maior parte do México para controlar doenças transmitidas por vetores de insetos. Os inseticidas foram particularmente importantes na campanha contra a malária, doença do Velho Mundo, tanto porque a malária demanda um custo em saúde e um custo econômico muito pesados quanto porque ainda não é controlável através de vacinaçôes, como é a febre amarela. A descoberta, em 1938, de que o DDT era eficaz para matar insetos e outros artrópodes, mas que tinha uma baixa toxicidade aguda para seres humanos, determinou seu uso generalizado na Segunda Guerra Mundial, particularmente no controle do tifo. O DDT logo despontou como uma solução aparentemente miraculosa para o controle da malária; as campanhas baseadas no DDT alcançaram taxas espetaculares de redução da malária em todo o mundo. No início dos anos 1960, contudo, surgiram dois problemas. Um era o rápido crescimento da resistência ao DDT em populações de mosquitos, causando um forte ressurgimento da malária em muitas regiôes. Os funcionários da saúde pública reagiam quase sempre aumentando as taxas de aplicação de DDT ou voltando-se para outros pesticidas que eram tão ou mais tóxicos aos seres humanos, uma mudança que ocorreu pelas mesmas razóes na agricultura. $\mathrm{O}$ segundo problema era o acúmulo de evidências de que o DDT estava causando significativos problemas ambientais. Como Rachel Carson observou em Silent spring, o DDT e outros pesticidas de sua classe são solúveis em gordura e, por conseguinte, armazenáveis em tecido animal e humano ${ }^{70}$. Eles também persistem sob a forma tóxica por longos períodos de tempo. Essas características causaram uma "exponenciação biológica” dos pesticidas e, consequentemente, sérios danos em organismos como aves de rapina, pelicanos e focas que vivem em níveis tróficos elevados. A evidência, lentamente acumulada, de que o DDT, embora somente causasse sintomas de envenamento agudo em seres humanos em taxas relativamente altas e dosagem pouco frequente, em doses baixas era provavelmente carcinogênico e perigoso para seres humanos numa variedade de modos crônicos e mais sutis. Níveis extraordinariamente elevados de DDT e seus produtos tóxicos disruptivos foram constatados no leite de mães em áreas onde o DDT estava sendo usado para o controle da malária e para o controle de pragas agrícolas, entre as quais certas regióes da Guatemala e nas planícies tropicais do México ${ }^{71}$.

A disseminação do uso de DDT para o controle da malária é uma das razôes pelas quais a companhia química nacionalizada pelo governo mexicano, a Fertempox, tornou-se a maior fabricante de DDT do mundo nos anos 1980. Nessa década, os empregados da saúde pública no México começaram a fazer a transição para outros métodos de controle da malária, incluindo pesticidas que não eram solúveis em gordura, eram persistentes e apresentavam uma toxicidade relativamente baixa para seres humanos (por exemplo, o Malathion), em combinação com medidas "higiênicas". Essas medidas incluíam o controle das áreas onde os mosquitos se reproduziam, infectando a larva do mosquito com organismos doentes, introduzindo peixes que se propagam com larva de mosquito, juntamente com a

\footnotetext{
${ }^{69}$ GUILLETTE, Elizabeth et al. An anthropological approach to the evaluation of preschool children exposed to pesticides in Mexico. Environmental Health Perspectives, v. 106, n. 6, p. 347-353, Jun. 1998.

${ }^{70}$ CARSON, Rachel. Silent spring. Nova York: Houghton Mifflin, 1962. O trabalho de Carson era pouco conhecido e pouco considerado no México, devido às preocupaçóes de alguns cientistas, em grande parte improcedentes, que invocavam a necessidade de controle da malária e de desenvolvimento econômico. Com o tempo, tornou-se muito conhecido; os agricultores mexicanos estavam passando a confiar sobretudo em organofosfatos e carbamatos não persistentes, mas muito mais tóxicos (cujos perigos Carson também discutiu, mas com menos repercussão entre o público e as autoridades reguladoras) devido ao acúmulo de resistência ao DDT e a outros organoclorados entre as populaçóes de insetos. Esse assunto é discutido em WRIGHT, Angus. The death of Ramon Gonzalez, op. cit. Especialmente p. 16-19.

${ }^{71}$ FRANCO AGUDELO, Saul. El paludismo en America Latina. Guadalajara: Universidad de Guadalajara, 1990.
} 
DESCENDO A MONTANHA E SEGUINDO PARA O NORTE: COMO A DEGRADAÇÃO DO SOLO E OS PESTICIDAS SINTÉTICOS ORIENTARAM A TRAJETÓRIA DA AGRICULTURA MEXICANA AO LONGO DO SÉCULO XX

$$
\text { Angus Wright }
$$

borrificação de inseticida em cima de alvos mais delimitados. O México virtualmente eliminou o uso do DDT para o controle da malária nos anos 1990. Todavia, o DDT permanece sendo um importante contaminador ambiental por ser um químico de longa duração, encerrar produtos tóxicos disruptivos e ser armazenado no tecido humano. Ele é usado ilegalmente porque é barato e de fácil obtenção. Hoje também compreendemos que o DDT e seus similares são poderosos agentes disruptivos endócrinos, o que quer dizer que podem ter efeitos multiplicadores sobre o desenvolvimento do feto e da criança e várias doenças em adultos, tais como infertilidade e endometriose. Outros pesticidas ainda estáo sendo empregados no controle da malária. Em áreas onde a exposição a pesticidas acontece tanto pelo seu uso na agricultura quanto na saúde pública, é particularmente importante entender o impacto de pesticidas em geral sobre seres humanos e sobre outros organismos e os efeitos cumulativos e sinergísticos da exposição a múltiplos pesticidas. Analiticamente, o problema é tão desafiador que não existe nenhuma resposta a curto prazo para ele, e devido ao alto custo que a tentativa de resolver as dificuldades científicas implica, pouco se investe em pesquisas a seu respeito, quer no México, quer em qualquer outro lugar do mundo.

\section{De uma crise à outra}

Nos anos 1980 e 1990, a maioria dos trabalhadores rurais sujeitos ao uso sistemático e abusivo de pesticidas fazia parte de populaçáo de falantes de línguas mixteca e zapoteca, oriundos de Oaxaca e de estados vizinhos. Os mixtecas eram os mais numerosos. Quando indagados sobre as razóes para a imigração, as respostas mais comuns referiam-se ao fato de que a terra de seus ancestrais não fornecia mais comida suficiente para que se continuasse a viver lá. Isso não era surpreendente, uma vez que a FAO classificara a regiấo habitada pelos mixtecas como uma das mais seriamente comprometidas pela erosão em todo mundo, com mais de $75 \%$ dos terrenos destruídos pela erosão do solo. O Serviço Federal de Conservação do Solo atuou por décadas na região, mas os resultados alcançados foram notadamente inócuos. Na década de 1980, o órgáo financiou um projeto em que uma máquina grande e cara construiu, num único movimento, um terraço inteiro acompanhando o contorno de um lado de uma montanha. O problema era que, ao fazer isso, sepultou muito abaixo da superfície o pouco que havia restado da camada superior do solo. Os agricultores locais não podiam se permitir economizar os talos de milho e outros materiais orgânicos que usavam como forragem para animais, mas que, comprovadamente, poderiam contribuir para a restauração da fertilidade dos terraços. Os contornos desses terraços assim construídos, por longos e impressionantes que fossem, acabaram sendo retomados, sobretudo, por ervas daninhas e mato e permaneceram como monumentos à beira da estrada a políticas e tecnologias equivocadas. Os trabalhadores agrícolas que trabalhavam no norte do México no último quartel do século XX estavam fugindo de um desastre ambiental para encontrar trabalho no meio de outra calamidade ambiental em andamento ${ }^{72}$.

O uso descontrolado e abusivo de pesticidas teve consequências agronômicas e ecológicas previsíveis, que incluem o rápido desenvolvimento da resistência ao pesticida entre organismos-alvo, incluindo insetos, sementes e patógenos de planta. Enquanto especialistas em desenvolvimento de plantas trabalham na produção de espécies mais resistentes a pragas, muitos agricultores respondem às pragas que resistem aos pesticidas basicamente aumentando a frequência e a dosagem das aplicaçóes desses pesticidas. Muitas pragas secundárias despontaram como problemas sérios em virtude da supressão de seus predadores pelo uso de pesticida contra outros organismos. Os pesticidas contaminam fontes locais de

${ }_{72}$ WRIGHT, Angus. The death of Ramon Gonzalez, op. cit. cap. 5. 
DESCENDO A MONTANHA E SEGUINDO PARA O NORTE: COMO A DEGRADAÇÃO DO SOLO E OS PESTICIDAS SINTÉTICOS ORIENTARAM A TRAJETÓRIA DA AGRICULTURA MEXICANA AO LONGO DO SÉCULO XX

Angus Wright

água, fazendas de camarão e o golfo da Califórnia ${ }^{73}$. A irrigação em larga escala e intensiva também acarretou consequências previsíveis, a saber, o sério aumento na salinidade do solo e problemas de drenagem que ameaçam a manutenção da produtividade das "novas terras" 74 .

Muitos observadores anteciparam que as negociaçóes sob o guarda-chuva do Tratado de Livre-Comércio da América do Norte (North-American Free Trade Agreement - Nafta) resultariam em leis e regulamentaçôes sobre pesticidas mais apropriadas ao México, bem como uma melhor política ambiental e uma melhor regulação em geral. Meticulosas negociaçôes produziram, com efeito, um conjunto de regulamentaçôes sobre pesticidas no México que é tão rigoroso quanto os padróes da Agência de Proteção Ambiental (Environmental Protection Agency — EPA) dos Estados Unidos. No entanto, há pouca evidência de que, na prática, isso tenha melhorado significativamente a situação. O estudo de Kevin Gallagher acerca das consequências ambientais do Nafta revela que em algumas áreas houve avanços no desempenho ambiental do México desde a implementação do tratado de liberalização do comércio. Esses avanços, contudo, são independentes, em sua maior parte, de quaisquer iniciativas promovidas pelo Nafta. No que diz respeito a muitas outras áreas, há leis melhores, mas seu cumprimento continua insatisfatório. A austeridade orçamentária no México, parte integrante do conceito mais amplo de liberalização econômica sob o Nafta, cortou a execução dos orçamentos até o limite em muitas áreas. As taxas de erosão do solo, em particular, aumentaram em $89 \%$ na primeira década após o $\mathrm{Nafta}^{75}$. Em 2008, analistas do Instituto Nacional de Ecologia mexicano chamaram a atenção para uma "situação alarmante", segundo a qual a degradação do solo afetava 45\% do território nacional, "podendo afirmar-se que a resposta institucional a essa situação continua a ser fraca e dispersa" ${ }^{76}$.

\section{A persistência de uma visão: agravamento ao invés de mudança?}

Uma visão, determinada e persistente, foi compartilhada pela Dinastia de Sonora, por Daniel Cosío Villegas, pela Fundação Rockefeller, por Ávila Camacho e, com uns poucos momentos de divergência, por todos os presidentes do PRI do século XX. Foi isso o que Cosío Villegas viu como solução para a pobreza "natural" dos solos do México através da irrigação, o que Avila Camacho viu como "a marcha para o mar" e o que os pesquisadores financiados pela Fundação Rockefeller viram como solução para a degradação dos solos mexicanos, pela abertura de novas terras, mediante novos cultivos e novas tecnologias. $\mathrm{O}$ radicalismo agrário de Zapata foi honrado em experiências extremamente controversas em alguns estados nos anos 1920 e durante pouco mais de quatro anos da administração de Lázaro Cárdenas, que se estendeu de 1935 a 1940 (seguindo, na época, um modelo de engenharia social que provavelmente não teria agradado Zapata). Pode-se dizer que ele foi desonrado por décadas de manipulação demagógica da causa camponesa por políticos do PRI, também preocupados com a "marcha para o mar". Uma abordagem alternativa, que teria reunido conservação do solo e ganhos de produtividade à reforma agrária, foi concebida, mas não efetivamente implementada, no longo prazo, pelo governo Cárdenas.

A abordagem da Revolução Verde sobre a erosão do solo no México significou o abandono dos pobres rurais mexicanos a seu destino, em solos considerados "esgotados" demais para estimular a força

\footnotetext{
${ }^{73}$ WRIGHT, Angus. The death of Ramon Gonzalez, op. cit. Posfácio.

${ }^{74}$ UMALI, Dina L. Irrigation-induced salinity: a growing problem for development and the environment. Washington, D.C.: World Bank, 1993. (World Bank Technical Paper 215).

${ }^{75}$ GALLAGHER, Kevin. Free trade and the environment: Mexico, Nafta, and beyond. Stanford: Stanford University Press, 2004; CAMPBELL, D.; BERRY, L. Land degradation in Mexico: its extent and impact. In: FAO. Lada working paper, 2003. Disponível em: <http://lada.virtual.centre.org>.

${ }_{76}^{76}$ COTLER, Helena et al. La conservación de suelos: un asunto de interés público. Gaceta Ecológica, v. 30, p. 5-71, 2007. Também disponível em: <http://www2.ine.gob.mx/publicaciones/gacetas/522/conservacion.html>.
} 
DESCENDO A MONTANHA E SEGUINDO PARA O NORTE: COMO A DEGRADAÇÃO DO SOLO E OS PESTICIDAS SINTÉTICOS ORIENTARAM A TRAJETÓRIA DA AGRICULTURA MEXICANA AO LONGO DO SÉCULO XX

$$
\text { Angus Wright }
$$

do desenvolvimento econômico do país. A irrigação de "novas terras" e o uso de pesticidas tornariam possível criar uma nova classe de empresários agrícolas que administraria as dimensôes do crescimento agrícola do país, enquanto ele tendesse a descer a montanha e a seguir para o norte. O que os políticos do PRI viam como um caminho para assegurar o crescimento econômico e as oportunidades representou, também, um fator signiticativo na ascensão ao poder de um novo partido político, o Partido de Ação Nacional (PAN), que encontra alguns de seus mais fortes partidários entre os líderes empresariais do agronegócio do norte desértico. (Um deles, um horticultor de Sinaloa, foi o primeiro candidato do PAN a concorrer, com alguma chance de êxito, à presidência do México, em 1988. O PRI buscou, sem sucesso, minar o apoio ao PAN, lançando outro empresário de Sinaloa como candidato nas eleiçóes de 2000.) Desde a ascensão da Dinastia de Sonora, em 1920, que o PRI veio preparando o terreno diligentemente, no sentido literal e no figurado, para sua própria ruína. O que foi considerado um novo começo com a queda do PRI e a ascensão do PAN pode significar mais o ápice desse processo do que uma mudança.

\section{Um novo começo é possível?}

Há uma história alternativa, um novo começo real possível para o México no futuro? Nos anos 1980, enquanto os agricultores mixtecas estavam deixando suas comunidades para trabalhar nos campos envenenados do Culiacán, alguns daqueles que haviam decidido permanecer em casa começaram a experimentar as formas tradicionais de agricultura e de controle de erosão mixtecas. Usando uma combinação de reflorestamento, terraços, fossos e pequenas represas, eles conseguiram restaurar uma extensão significativa de terras. Jesus Leon Santos, um agricultor mixteca, ganhou o Prêmio Ambiental Goldman em 2008, por conta de seu trabalho com o Centro para o Desenvolvimento Integral dos Pequenos Agricultores (Cedicam), na região norte de Oaxaca. A organização trabalha com mais de 1.500 agricultores em doze comunidades. O Cedicam afirma ter plantado mais de 1 milhão de árvores e ter protegido ou restaurado cerca de 7 mil hectares de terra, lançando máo de terraços e muros de pedra e outras técnicas, o que acarretou um aumento de $50 \%$ na produção agrícola. Afirma-se que comunidades que eram capazes de aproveitar apenas 25 a 30\% de suas terras agora estáo usando $80 \%$. Com o aumento da retenção de água, as nascentes estão voltando à vida. Agricultores estão gradualmente abandonando o uso de pesticidas e fertilizantes sintéticos, adaptando técnicas tradicionais e sementes, e aprendendo novos métodos de agricultura sustentável. Movimentos semelhantes estão tendo lugar em outras áreas do México ${ }^{77}$.

Serão essas pessoas e organizaçóes inconsequentes e transitórias, ou será que elas vão demonstrar ter uma importância transformacional, enquanto a agricultura mexicana adapta-se aos problemas criados por ela mesma e à mudança climática global? Será que, em última instância, eles precisam do apoio maciço do Estado que tornou a Revolução Verde possível, ou será que podem prosperar por conta própria? Será que vão demandar ou provocar novas mudanças no poder político? Seria muito ousado sugerir que o nascente movimento da agricultura sustentável entre os pobres das zonas rurais do México se tornará importante na vida mexicana. O pleno poder do Estado mexicano, sustentado por alianças de apoio com os círculos empresariais e financeiros e com o governo dos Estados Unidos, corre na direção oposta desde mesmo antes da Revolução Mexicana. Qualquer estratégia para a mudança terá de lidar com essa persistente realidade.

${ }_{77}^{77}$ JESUS, Leon Santos, Goldman Prize 2008. Disponível em: <www.goldmanprize.org/node/713>. Acesso em: 21 abr. 2010. 